\title{
En Hafif Kafes Yapı Tasarımı için Bakteri Yiyecek Arama Optimizasyon Algoritmasının Parametre Analizi
}

\author{
Burak KAYMAK $* 1$ \\ ${ }^{1}$ Kütahya Dumlupınar Üniversitesi, Mühendislik Fakültesi, İnşaat Mühendisliği Bölümü, 43100, Kütahya, Türkiye \\ (ORCID: https://orcid.org/0000-0002-1318-0456)
}

(Alınıs / Received: 03.04.2019, Kabul / Accepted: 03.07.2019, Online Yayınlanma / Published Online: 30.08.2019)

\author{
Anahtar Kelimeler \\ Bakteri yiyecek arama \\ optimizasyonu, \\ Parametre analizi, \\ Optimum tasarım, \\ Kafes yap 1
}

\begin{abstract}
Özet: Topolojisi belirli kafes yapıların en hafif tasarımının elde edilmesi problemi kesit alanlarının belirlenmesine yönelik bir optimizasyon problemidir. Optimizasyon probleminin çözümünde sürü tabanlı yöntemlerden olan bakteri yiyecek arama optimizasyon algoritması tercih edilmiştir. Bu algoritmanın en hafif kafes yapı tasarımı problemlerinin çözümünde başarı ile kullanması için seçilmesi gereken parametrelerin neler olması gerektiği üzerine çalışılmıştır. Algoritmanın parametreleri ikili gruplar halinde değiştirilerek sonuca etkileri araştırılmıştır. Ek olarak algoritmadan alınacak sonuca büyük oranda etki eden adım uzunluğu parametresinin seçiminde baştan sona sabit bir değer kulanılması yerine üreme sayılarına bağlı olarak değiş̧tirilmesi önerilmektedir. Elde edilen bulgular sonunda en hafif kafes tasarımı problemleri için uygun parametreler belirlenmiştir. Sürü tabanlı optimizasyon yöntemleri rastgele noktalardan başladıklarından her çalıştırma sonunda elde edilen sonuçlar da farklılık göstermektedir. Elde edilecek sonuçların birbirine olan yakınlığı algoritmanın kararlılı̆̆ının bir göstergesidir. Çalışma sonunda ortaya çıkan parametreler kullanılarak üç örnek problem üzerinde yapılan analiz sonuçlarının varyasyon katsayılarının \%0.7'nin altında olduğu görülmüştür. Bu çalışmada elde edilen bakteri yiyecek arama optimizasyon algoritması parametrelerinin en hafif kafes yapı tasarımı problemlerinde kullanılabilir olduğunu göstermektedir.
\end{abstract}

\section{Parameter Analysis of Bacterial Foraging Optimization Algorithm for Least Weight Design of Truss Structures}

\section{Keywords}

Bacterial foraging optimization,

Parameter analysis, Optimum design,

Truss structure

\begin{abstract}
The problem of obtaining the least weight design of truss structures with a fixed topology is an optimization where the cross-sectional areas are determined. In order to solve the optimization problem, bacterial foraging optimization algorithm which is one of the swarm-based methods is chosen. In this work it is studied that which parameters should be chosen for successful application of the algorithm in the solution of the least weight design of truss structures. The parameters of the algorithm are collected in dual groups and their effects are investigated. Additionally, it is recommended to change the step length parameter, which greatly influences the results depending on the reproduction numbers rather than using a constant value from the beginning to end. At the end, the appropriate parameters are determined for least weight truss design problems. Since swarm-based optimization methods start at random points, the results obtained at the end of each run differs. The proximity of the results to be obtained is an indicator of the stability of the algorithm. It is seen that the coefficient of variation of the analysis results using the parameters obtained at the end of the study was below $0.7 \%$. The bacterial foraging optimization algorithm parameters obtained in this study show that these parameters can be used for least weight truss structure design.
\end{abstract}

\section{Giriş}

Kafes yapılar endüstriyel yapılardan uçak-uzay sanayine kadar birçok alanda sıklıkla kullanılan yapılardır. Son elli yılda bu yapıların tasarımını yapmak üzere optimizasyon yöntemleri kullanılmaktadır. Optimizasyon yöntemlerinin ortaya çıktığ1 erken dönemlerde lineer programlama, kesme düzlemi gibi matematik metodlar kullanılmıştır. Ancak kafes optimizasyon problemleri nonlineer özellik gösterdiklerinden dolayı sonuçların elde edilmesi uzun zaman alabilmektedir. Son yirmi, özellikle on yılda ise 
evrimsel veya sürü tabanlı sezgisel yöntemler problemin lineer veya nonlineer olma özelliklerinden çok da fazla etkilenmediklerinden dolayı oldukça popüler hale gelmişlerdir.

Kafes yapıların sezgisel yöntemlerle sürekli değişkenli optimizasyonu ilk olarak 1964'de Dorn ve diğerleri[1] tarafından ortaya atılmıştır. Rajeev ve Krishnamoorthy 1997 yılında kafes yapıların genetik algoritma(GA) ile optimum tasarımlarını gerçekleştirmişlerdir[2]. Dorigo ve Caro[3] karınca koloni optimizasyon algoritmasını(ACO) kesikli değişkenli problemlerin çözümünü elde etmek üzere 1999 yılında ortaya koymuşlardır. Yapay karınca optimizasyon algoritmasının kafes yapılar üzerindeki uygulaması Kaveh ve Talatahari[4] tarafindan 2009 yılında yapılmıştır. Bir diğer sezgisel yöntem olan armony arama(HS) algoritması Geem ve diğ.[5] tarafindan 2001 yılında kafes yapıların optimum tasarımını elde etmek üzere kullanılmıştır. Tabu arama(TS) algoritması Glover[6, 7] tarafından 1990 yılında önerilmiş ve Bannage ve Dhingra[8] bu sezgisel yöntemi kafes yapıların optimimum topolojisini elde etmekte kullanmışlardır. Oldukça yaygın kullanım alanı bulunan parçacık sürü optimizasyon(PSO) algoritması Kennedy ve Eberhert[9] tarafindan 1995 yılında önerilerek sezgisel yöntemler arasında yerini almıştır. PSO algoritmasının kafes yapılarda uygulamasını Schutte ve Groenwold[10] gerçekleştirmişlerdir. Karaboğa ise 2005 yılında arıların davranışlarını model alan yapay arı optimizasyon algoritmasını ortaya koymuştur[11]. Karaboğa'nın[11] 2005 yılında önerdiği yapay arı optimizasyon yöntemini Sönmez 2011'de kafes yapıların optimum tasarımını elde etmek üzere kullanmıştır[12, 13]. Sürü tabanlı sezgisel optimizasyon yöntemlerinden bir diğeri olan bakteri yiyecek arama optimizasyonu(BFO) Kevin Passino tarafindan 2002 yılında önerilmiştir[14].

Bakteri yiyecek arama optimizasyon algoritması birçok araştırmacı tarafından çeşitli problemlerin optimum çözümlerini elde etmek amacıyla kullanılmıştır[15-19]. Bunların bir kısmı algoritmanın performansını artırmak amacı taşıyan iyileştirmeler olmuştur[20-22]. Bakteri yiyecek arama optimizasyon algoritması kisitları bulunmayan problemlerin optimumlarını bulmak üzere geliştirilmiş olup daha önce çeşitli araştırmacılar[12, 2326] tarafindan Deb'in[27] kuralı uygulanarak kisıtlı optimizasyon problemlerinin çözümü gerçekleştirilmiştir. Bu çalışmada da BFO üzerinde Deb'in kuralı uygulanarak kısitlı optimizasyon problemlerinden olan topolojisi belirli en hafif kafes yapı tasarımı problemi ele alınmıştır.

Parpinelli ve çalışma arkadaşları[28] BFO algoritması kullanılarak yapısal mühendislik problemlerinin optimum çözümlerini elde etmeyi amaçlayan bir çalışma gerçekleştirmişlerdir. Bahsi geçen çalışmada bir kafes yapının en hafif tasarımını ele alan bir örnek problem yer almasına karşın BFO algoritmasının parametrelerinin seçimi konusunda nasıl karara varıldığ 1 ile ilgili bilgi bulunmamaktadır. Oysa ki bu tür algoritmalarda kullanılan parametreler ulaşılan hedef noktanın ne oranda güvenilir ve tekrarlanabilir bir sonuç olduğuna etki etmektedir. Bu çalışmada kafes yapıların en hafif tasarımını elde etmek üzere BFO algoritması kullanılmış olup daha güvenilir, yaklaşım hızı daha az olan ve tekrarlanabilir sonuçların elde edilmesine hizmet edecek parametrelerin seçimi için iki örnek problem üzerinde bir seri optimizasyon analizleri gerçekleştirilmiştir. Elde edilen bulgular değerlendirilerek kafes yapıların en hafif tasarımını güvenilir biçimde elde etmeyi sağlayacak parametreler belirlenmiş olup örnek kafes yapılar üzerinde elde edilen parametreler kullanılarak optimizasyon algoritması çalıştırılmış elde edilen sonuçlar değerlendirilmiştir. BFO algoritmasının iki örnek kafes yapı üzerinde kullanılacak parametrelerin belirlenmesinin ardından üçüncü bir örnek problem üzerinde de test edilmiştir. Sonuçlar göstermektedir ki bu çalışmada ortaya konulan parametreler kullanılarak gerçekleştirilen en hafif kafes yapı tasarımları için güvenilirlik, yaklaşım hızı ve tekrarlanabilirlik oldukça uygun seviyelerdedir. Ek olarak BFO algoritmasından elde edilecek sonucu önemli derecede etkileyen adım uzunluğu parametresiyle ilgili olarak çalışma kapsamında bir yaklaşım önerilmektedir. Önerilen yaklaşım ile daha az yapı analizi gerçekleştirilerek optimum sonuçların elde edilmesi mümkün olmaktadır.

Makale 6 bölümden oluşmakta olup 2. bölümde kafes yap1 optimizasyon problemi tanımlanmıştır. 3. bölümde bakteri yiyecek arama optimizasyon algoritmasına ve algoritmanın yalancı koduna yer verilmiştir. BFO algoritmasının parametre sayısının fazla olması sebebiyle her seferde iki parametrenin sonuçlara etkisi incelenmiştir. Öncelikle adım uzunluğu ve yüzme sayılarının ardından önerilen değişken adım uzunluğu stratejisinin, takiben bakteri sayısı ve kemotaksis sayısının etkileri incelenmiştir. Ardından üreme ve ortadan kaldırma-yeniden dağılma sayılarının etkisi ve son olarak da sürü etkileşiminin etkisi ele alınmıştır. Bakteri yiyecek optimizasyon algoritması kullanılarak gerçekleştirilen analizler neticesinde elde edilen bulgular bölüm 4'de yer almaktadır. Tartışma ve sonuç bölüm 5'de verilmektedir.

\section{Kafes Tasarım Problemi}

Ele alınan kafes tasarım problemi topolojisi belirli olan kafes yapının dügüum noktalarında izin verilen deplasman limitleri ve çubuklarında oluşacak gerilmelerin kısıtlanması ile ortaya çıkan optimizasyon problemidir.

Kafes yapının denge denklemleri Eş.(1)'de tarif edilmektedir. Burada $B_{i j}$, denge deklemi katsayılarını, $F_{j l}, l$ yüklemesi altıdaki kafes yapının $j$ çubuğunda oluşan kuvveti, $P_{i l}$ ise $l$ yüklemesi altında $i$ serbestliği doğrultusundaki düğüm yükünü gösterir. Eş.(2)'de tümleşik olarak kafes yapının bünye ve uygunluk denklemleri verilmiştir. Burada $L_{j}, A_{j}$ ve $E_{j}$ sirasıyla $j$ çubuğunun uzunluğunu, kesit alanını, elastisite modülünü göstermektedir. $x_{i l}$ ise $l$ yüklemesi altında $i$ serbestliğinde meydana gelen deplasmandır. $B_{j i}$ uygunluk denklemi katsayılarıdır. Eş.(4), Eş.(5) ve Eş.(6) sırasıyla kafes optimizasyon probleminin gerilme, deplasman ve kesit alanı kısıtlarıdır. $\sigma_{j l}, l$ yüklemesi altındaki kafes yapının $j$ çubuğunda oluşan gerilmeyi, $\sigma_{j l}^{a}$, gerilme alt limitini, $\sigma_{j l}^{u}$, gerilme üst limitini göstermektedir. $x_{i l}^{a}$, deplasman alt limitini, $x_{i l}^{u}$ ise deplasman üst limitini göstermektedir. Kesit alanları alttan $A_{j}^{a}$ ve üstten $A_{j}^{u}$ ile sınırlandırılmıştır. Kafes yapının serbestlik derecesi $s d$, çubuk sayısı $m$ ve yükleme sayısı $k$ ile gösterilmiştir. 


$$
\begin{gathered}
\sum_{j=1}^{m} B_{i j} F_{j l}=P_{i l} \\
F_{j l}=\frac{A_{j} E_{j}}{L_{j}} \sum_{i=1}^{s d} B_{j i} x_{i l} \\
F_{j l}=A_{j} \sigma_{j l} \\
\sigma_{j l}^{a} \leq \sigma_{j l} \leq \sigma_{j l}^{u} \\
x_{i l}^{a} \leq x_{i l} \leq x_{i l}^{u} \\
A_{j}^{a} \leq A_{j} \leq A_{j}^{u} \\
i=1,2, \ldots, s d, \quad j=1,2, \ldots, m, \quad l=1,2, \ldots, k
\end{gathered}
$$

Eş.(2)'de deplasmanlar cinsinden tarif edilen çubuk kuvvetleri Eş.(1)'de yerine koyulursa kafes yapı denge denklemleri deplasmanlar cinsinden tarif edilmiş olur.

$$
\underbrace{\left[\sum_{j=1}^{m} B_{i j}\left(\frac{A_{j} E_{j}}{L_{j}}\right) \sum_{i=1}^{s d} B_{j i}\right]}_{\text {Kafes yapının rijitlik matrisi }} x_{i l}=P_{i l}
$$

Ortaya çıkan lineer denklem takımının çözümü kafes yapının deplasmanlarını verir. Eş.(3) ve Eş.(2) düzenlenirse kafes yapının çubuklarında oluşan gerilmelerin deplasmanlar cinsinden tarifi aşağıdaki gibi elde edilebilir.

$$
\sigma_{j l}=\frac{E_{j}}{L_{j}} \sum_{i=1}^{s d} B_{j i} x_{i l}
$$

Kafes optimizasyon probleminin amaç fonksiyonu Eş.(9)'daki gibi tarif edilmektedir. Burada $\rho$ kullanılan malzemenin birim hacim ağırlığını göstermektedir. Eş.(9)'da çubukların kesit $\operatorname{alanı}\left(A_{j}\right)$ tasarım değişkeni olarak alınmıştır.

$$
\operatorname{Min} W=\sum_{j=1}^{m} A_{j} L_{j} \rho
$$

Eş.(7)'nin çözümünden kafes yapının deplasmanları elde edilir. Deplasmanların Eş.(8)'de yerine koyulmasıyla da kafes yapının çubuklarında oluşacak gerilmeler elde edilmiş olur. Elde edilen deplasmanlar ve gerilmeler aşağıdaki gibi kafes optimizasyon probleminin normalize edilmiş kısıtları haline dönüştürülür.

$$
\begin{aligned}
& \frac{\sigma_{j l}}{\sigma_{j l}^{\text {limit }}}-1 \leq 0 \\
& \frac{x_{i l}}{x_{i l}^{\text {limit }}}-1 \leq 0
\end{aligned}
$$

Eş.(10) kafes optimizasyon probleminin normalize edilmiş gerilme kısıtı olup $\sigma_{j l}^{\text {limit }}, l$ yüklemesi altındaki kafes yapının $j$ çubuğunda izin verilen gerilme limitini tarif eder. Eş.(11) kafes optimizasyon probleminin normalize edilmiş deplasman kısıtı olup $x_{i l}^{\text {limit }}, l$ yüklemesi altındaki kafes yapının $i$ serbestliğinde izin verilen deplasman miktarıdır. Eş.(10) ve Eş.(11) tasarım değişkenleri olan çubuk kesit alanlarına doğrusal olmayan şekilde bağlı olduğundan amaç fonksiyonu doğrusal ancak kısıtları doğrusal olmayan optimizasyon problemi olarak sinıflandırılmaktadır.

\section{Bakteri Yiyecek Arama Optimizasyonu}

Bakteri yiyecek arama algoritması bakterilerin yiyecek arama davranışı temel alınarak Passino[14] tarafindan türetilmiştir. Bu algoritma diğer sürü tabanlı algoritmalar gibi eğimin analitik tanımına ihtiyaç duymaz. Bu nedenle doğrusal olmayan optimizasyon problemlerinde rahatlıkla kullanilabilir.

Bir bakterinin içinde bulunduğu ortam $\theta$ ile tanımlı olmak üzere $J(\theta)$ ortamın kalitesi ile ilgili bilgiyi verir. Eğer $J(\theta)<0$ ise besin açısından zengin olan bir ortam, $J(\theta)=0$ ise doğal ve $J(\theta)>0$ ise zararlı ortam olduğu anlaşılır[14]. Amaç yiyecek bakımından zengin ortama ulaşmaktır. BFO algoritmasının kemotaksis, üreme ve ortadan kaldırma-yeniden dağılma olmak üzere üç temel operasyonu bulunur.

Kemotaksis operasyonu; bakterinin ortam içindeki hareketlerini tarif eder. $\mathrm{Bu}$ hareketler yuvarlanma ve yüzme olmak üzere iki çeşittir. Yuvarlanma hareketi Eş.(12)'de belirtildiği gibi gerçekleşir.

$$
\theta^{i+1}(j+1, k, l)=\theta^{i}(j, k, l)+C(i) \frac{\Delta(i)}{\sqrt{\Delta^{T}(i) \Delta(i)}}
$$

Burada $\theta^{i}, i$. Bakterinin $j$. kemotaksis adımında $k$. üreme, ve $l$. ortadan kaldırma-yeniden dağılma adımındaki konumunu belirtir. $\theta^{i+1}$ ise ayn bakterinin kemotaksiste bir adım ilerlemesi durumundaki pozisyonudur. $C(i)$, $i$. bakterinin adım uzunluğudur. $\Delta(i)$ optimizasyon probleminin boyutu kadar elemanı bulunan ve $[-1,1]$ değerleri arasında rastgele reel sayılardan oluşan bir vektördür.

Eş.(12) kullanılarak herhangi bir bakteri için daha iyi bir ortama geçiş yapılabilmişse bu durumda aynı doğrultuda hareket edilmeye devam edilir. Bu olay yüzme olarak adlandırılmaktadır. Yüzme hareketinin sonlanmasına ya belirlenen yüzme uzunluğunun sonuna gelinmesi ya da yeni pozisyondaki yiyecek miktarının bir öncekinden daha az olması yani daha kötü bir ortama geçilmiş olmasına göre karar verilir.

Kemotaksis operasyonları sırasında her bir bakterinin sağlık durumu aşağıdaki gibi kayıt altına alınır.

$$
J_{\text {health }}^{i}=\sum_{j=1}^{N c+1} J(i, j, k, l)
$$

Eş.(13)'de elde edilen değer $i$. Bakterinin kemotaksis operasyonu sonundaki sağlık durumunu gösterir. Minimizasyon problemleri için düşük değer daha sağlıklı bir bakteriyi tarif eder.

Kemotaksis operasyonunun sonlanmasının ardından bakteriler en sağlıklıdan daha az sağlıklı olana doğru sıralanır. Popülasyondaki bakterilerin sağlık durumu daha kötü olan yarısı ölür. Geri kalan bakteriler ise bölünerek ürerler. Diğer bir deyişle mevcut(sağ kalan) bakterilerin bir kopyası meydana gelir. Bu adım üreme operasyonu olarak isimlendirilir[14].

Üreme operesyonları daha önceden tespit edilen belirli bir sayıya eriştiğinde $P_{e d}$ olarak tarif edilen olasılık değerine bağlı olarak bakterilerin bir kısmı ölür ve çözüm uzayında 
rastgele bir noktada yeni bir bakteri meydana gelir. Bu işlem de ortadan kaldırma-yeniden dağılma operasyonu olarak isimlendirilir[14]. Bu çalışmada olasılık değeri klasik BFO için Passino'ya bağlı kalınarak $P_{e d}=0.25$ olarak alınmıştır. Ortadan kaldırma-dağılma operasyonu lokal optimuma takılma ihitimalini azaltmak amacı ile gerçekleştirilmektedir.

Bakteri yiyecek arama algoritmasında hücreden hücreye bilgi aktarımı bir diğer deyişle sürü etkileşimi Eş.(14) ve Eş.(15)'nin Eş.(13)'e eklenmesiyle mümkün olur.

$$
\begin{aligned}
& \sum_{i=1}^{s}\left[-d_{\text {attract }} \exp \left(-w_{\text {attract }} \sum_{m=1}^{p}\left(\theta_{m}-\theta_{m}^{i}\right)^{2}\right)\right] \\
& \sum_{i=1}^{s}\left[h_{\text {repellant }} \exp \left(-w_{\text {repellant }} \sum_{m=1}^{p}\left(\theta_{m}-\theta_{m}^{i}\right)^{2}\right)\right]
\end{aligned}
$$

Burada s, bakteri sayısı, p, tasarım değişkenleri sayısı, $\theta_{m}^{i}$, $i$. bakterinin $m$. tasarım değişkeni değeri, $\theta_{m}, m$. tasarım değişkeni için ilgili değişkenin alt ve üst sınırları arasında rastgele bir değerdir. $d_{\text {attract }}, w_{\text {attract }}, h_{\text {repellant }}$ ve $w_{\text {repellant }}$ yönteme ait sabitler olup Passino[14] tarafinda aşağıdaki gibi verilmektedir.

$$
\begin{array}{llr}
d_{\text {attract }}= & 0.1 \\
w_{\text {attract }}= & 0.2 \\
h_{\text {repellant }}= & 0.1 \\
w_{\text {repellant }}= & 10.0
\end{array}
$$

Yap1 analizi ve optimizasyon algoritması $\mathrm{C}++$ programlama dili kullanılarak bir bütün olarak kodlanmıştır. Bakteri yiyecek arama optimizasyon algoritması için yalancı kodlar aşağıdaki gibi tarif edilebilir.

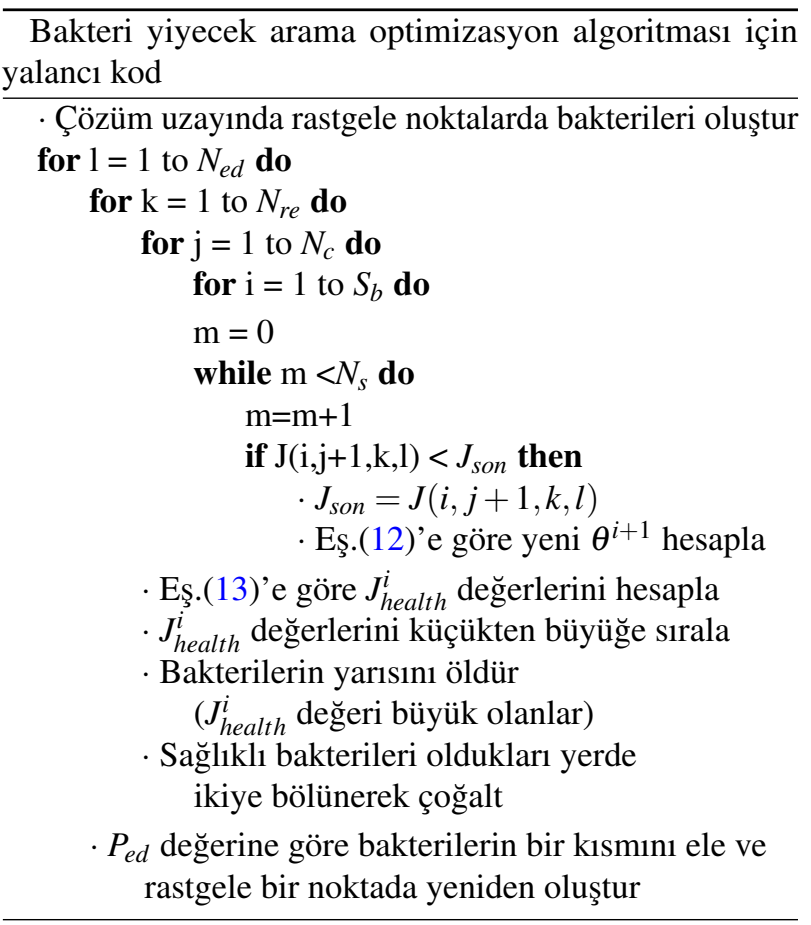

Burada $N_{e d}$ ortadan kaldırma-yeniden dağılma operasyonları sayısını, $N_{r e}$ üreme operasyonları sayısın1, $N_{c}$ kemotaksis operasyonları sayısını, $N_{s}$ yüzme operasyonları sayısını, $S_{b}$ ise bakteri sayısını göstermektedir. $J(i, j+1, k, l) j+1$. kemotaksis adımında, $k$. üreme adımında, $l$. ortadan kaldırma-yeniden dağılma adımındaki $i$. bakterinin amaç fonksiyonu değerini gösterir. $\theta^{i+1}$ ise yukarıda tarif edilen durumdaki bakterinin çözüm uzayındaki pozisyonudur. Tasarım değişken sayısı kadar elemanı olan bir vektördür.

\subsection{BFO algoritmasının parametrelerinin incelenmesinde uygulanan yöntem}

Bir önceki bölümde belirtildiği üzere bakteri yiyecek arama algoritmasının kemotaksis, üreme ve ortadan kaldırma-yeniden dağılma olmak üzere üç aşaması bulunmaktadır. Kemotaksis aşaması kendi içinde yüzme ve yuvarlanma olmak üzere ikiye ayrılır. $\mathrm{Bu}$ üç temel aşamada yüzme de dahil olmak üzere dört farklı parametre değerinin belirlenmesi ulaşılacak sonucun kalitesini etkiler. Bunların yanında her yeni pozisyon belirlemede Eş. (12) gereğince adım uzunluğunun $(C(i))$ büyüklüğü elde edilecek sonucu etkileyen parametrelerden bir diğeridir. Bir başka parametre ise ortadan kaldırma-yeniden dağılma aşamasında rastgele olarak seçilen bakterilerin bir kısmının ölmesi ve çözüm uzayında rastgele noktalarda konumlandırılması işleminde kullanılan olasılık değeri $P_{e d}$ 'dir. Bu çalışmada Passino'nun çalışmasına bağlı kalınarak olasılık değeri $P_{e d}=0.25$ olarak alınmıştır. Orijinal BFO algoritmasının iterasyon, adım uzunluğu ve olasılık değeri dişında bir grup parametresi daha bulunmaktadır. Sürü etkileşimi olarak adlandırılan etkinin dikkate alınması durumunda kullanılacak parametreler Passino[14] tarafından Eş. (16)'da verildiği gibi ele alınmıştır. $\mathrm{Bu}$ çalışma kapsamında sürü etkileşimi parametreleri üzerine çalışılmamıştır. Ancak sürü etkileşiminin etkisinin olup olmadığı çalışma kapsamında değerlendirilmiştir.

BFO algoritmasının çok sayıda parametresi olması sebebiyle her bir parametrenin farklı değer alması durumunda ortaya çıkan kombinasyon sayısı çok fazla olacağından bu çalışmada parametreler ikili gruplar haline getirilerek kombinasyonlar oluşturulmuş ve bunun elde edilen sonuçlara etkisinin incelenmesi yöntemi tercih edilmiştir. Her aşamada etkileri incelenen iki parametre dişındaki parametreler sabit olarak tutulmuştur. Sabit tutulan parametre değerleri ilgili alt bölümlerde belirtilmektedir.

\subsection{Adım uzunluğu ve yüzme sayısının incelenmesi}

BFO algoritmasında optimum çözüme ulaşmada adım uzunluğu yöntemin önemli parametrelerden biridir. Adım uzunluğunun büyük seçilmesi durumunda yaklaşım hızı istenen seviyelerde olurken optimum nokta üzerinden atlanarak geçilmesi durumları ile karşılaşılabilir. Adım uzunluğunun küçük seçilmesi halinde ise optimum noktanın yakalanma ihtimali artmasına rağmen yaklaşım hızı çok yavaş kalabilir. Bazı durumlarda optimum noktaya erişebilmek için çok fazla sayıda iterasyon yapılması gerekebilir. $\mathrm{Bu}$ nedenle adım uzunluğunun seçimi önemlidir. 
Yüzme sayısı $\left(N_{S}\right)$, bir bakterinin doğrultusu belirlenmiş bir yönde en fazla kaç adım atabileceğini tanımlar. Eğer bakteri bir doğrultuda ilerlerken daha iyi bir ortama geçiyorsa(besin olarak zengin veya zararlı etkilerin bulunmadığı) belirlenen yüzme sayısına ulaşana kadar o ortamda yüzmeye devam eder(yüzme sayısı sınırına ulaşıldığında yön değiştirme işlemi gerçekleştirilir), daha kötü bir ortama geçmesi durumunda yüzme işlemi sonlandırılıp yön değiştirme işlemi gerçekleştirilir. Zengin ortamda bulunan bakterinin yüzme sayısı kısıtlanırsa optimuma doğru ilerlemesi durumunda yüzmenin hemen ardından yön değiştirme yapılacağı için muhtemel bir optimum noktanın kaçırılması gündeme gelebilir. $\mathrm{Bu}$ nedenle yüzme sayısının büyüklügü önemlidir.

Yüzme sayısı ve adım uzunluğu parametrelerinin etkilerini gözleyebilmek amacıyla farklı adım uzunlukları ve farklı yüzme sayısı değerleri için BFO algoritması her iki örnek problem için çalıştırılmıştır. Burada kullanılan yüzme sayısı değerleri $N_{s} \in\{10,100,1000\}$ olarak ve adım uzunlukları da $C(i) \in\{20,2,0.5,0.1,0.05,0.01\}$ olarak kullanılmıştır. Adım uzunluğu ve yüzme sayılarının etkilerini belirlemek amaciyla bu aşamada algoritmada kullanılan diğer parametler şöyledir: $S_{b}=40, N_{c}=20$, $N_{r e}=20, N_{e d}=5$. Bunlara ek olarak sürü etkileşimi ihmal edilmiştir.

\section{3. Önerilen adım uzunluğu stratejisi}

Adım uzunluğunun BFO algoritmasından elde edilecek optimum değer üzerindeki etkisinin son derece önemli olduğu Şekil 4 ve Şekil 5'de açıkça görülmektedir. Adım uzunluğunun problemin başında sabit olarak belirlenmesi bu haliyle bir deneme-yanılma süreci gerektirmektedir. Bir problem için uygun sonuç veren adım uzunluğu bir başka problem için çok uygun olmayan sonuçlar verebilir. $\mathrm{Bu}$ gibi durumların önüne geçebilmek amacıyla bu çalışmada adım uzunluğunun her üreme iterasyonu bitiminde bakterilerin adım uzunluğunun yarıya düşürülmesi yoluyla değiştirilmesi önerilmektedir.

$$
C(i)_{j}=\frac{C(i)_{j-1}}{2} \quad j=1,2, \ldots, N_{r e}
$$

Burada $C(i)_{j} \quad i$ bakterisinin $j$. üreme adımındaki adım uzunluğunu belirtir. Her üreme iterasyonu sonunda bakterilerin tamamının adım uzunluğu yarıya düşürülür. Böylece başlangıçta daha büyük adımlar atan bakteriler yeni jenarasyonlarda adım sayılarını küçültmüş olacaklardır. Burada amaç optimum noktaya yaklaştıkça adım uzunluklarını küçültmek suretiyle daha hassas arama yapmaktır. Önerilen adım uzunluğu stratejisinin etkilerini incelemek üzere kafes yapı örneklerinin ikisi için de $S_{b}=40, N_{s}=100, N_{c}=50, N_{r e}=20$ ve $N_{e d}=5$ parametreleriyle BFO algoritması çalıştırılmıştır. Başlangıç adım uzunluğu $C(i)_{0}=20.0$ olarak alınmıştır. Sürü etkileşimi ihmal edilmiştir.

\subsection{Bakteri ve kemotaksis sayılarının incelenmesi}

Adım uzunluğu ve yüzme sayılarının algoritmanın yaklaşım hızına olan etkilerinin incelenmesinin ardından adım uzunluğunun değişken olarak kullanılmasının algoritmadan elde edilen sonuçları iyileştirdiği görülmüştür(Şekil 6 ve Şekil 7). Bu nedenle çalışmanın sonraki aşamalarında önerilen adım uzunluğu stratejisi tercih edilerek algoritmada kullanılacak bakteri $\operatorname{sayı\operatorname {sin}ı}\left(S_{b}\right)$ ve kemotaksis $\operatorname{sayısının}\left(N_{c}\right)$ ulaşılan optimum noktaya etkisi incelenmiştir. Bunun yanında algoritmanın başlangıç noktalarını rastgele belirlemesi nedeniyle farklı zamanlarda çalıştırılması durumunda ulaşılan optimum noktaların birbirinden ne kadar dağınık, başka bir deyişle ne kadar yakın elde edilmesine etki ettikleri tespit edilmeye çalışılacaktır. $\mathrm{Bu}$ amaçla bakteri say1s1 20, 40, 60, 80 ve 100 olmasi durumunda ve kemotaksis sayıs1 10'dan 100'e $\operatorname{kadar}(100$ dahil) 10 'ar adım artışlarla elde edilen kemotaksis sayıları kullanıllarak algoritmanın 30 defa bağımsız çalıştırılması durumunda elde edilen ortalama yapı ağırlıkları ile varyasyon katsayısının $\left(V_{k}\right)$ değişimi incelenmiştir. Bakteri sayısı ve kemotaksis sayısı dışındaki parametreler şöyle kullanılmıştır: $N_{s}=100, N_{r e}=20, N_{e d}=5$ ve başlangıç adım uzunluğu $C(i)_{0}=20.0$. Sürü etkileşimi ihmal edilmiştir.

\section{5. Üreme ve ortadan kaldırma-yeniden dağılma sayılarının incelenmesi}

Üreme sayısı $\left(N_{r e}\right)$ ve ortadan kaldırma-yeniden dağılma $\operatorname{say} \sin ı n\left(N_{e d}\right)$ algoritmadan elde edilecek sonuca ne oranda etki ettiğini belirlemek amacıyla farklı üreme sayıları $\left(N_{r e} \in\{5,10,20\}\right)$ ve farklı ortadan kaldırmayeniden dağılma sayıları $\left(N_{e d} \in\{2,5,10\}\right)$ kullanılmıştır. Üreme ve ortadan kalırma-yeniden dağılma sayılarının etkileri incelenirken bakteri adım uzunluğu parametresi -bu çalışmada önerilen- her üreme adımında adım uzunluğunun yarıya düşürülmesi stratejisi kullanılarak değişken olarak alınmıştır. Bunun için başlangıç adım uzunluğu $C(i)_{0}=20.0$ olarak seçilmiştir. Üreme sayısı ve ortadan kaldırma-yeniden dağılma sayılarının etkileri incelenirken Şekil 8, Şekil 9, Şekil 10 ve Şekil 11 dikkate alınarak bakteri sayısının $S_{b}=40$, kemotaksis sayısı $N_{c}=$ 50 ve yüzme sayısı $N_{s}=100$ ve başlangıç adım uzunluğu $C(i)_{0}=20.0$ olacak şekilde algoritma çalıştırılmıştır. Sürü etkileşimi ihmal edilmiştir.

\subsection{Sürü etkileşiminin incelenmesi}

Son olarak sürü etkileşiminin etkilerini incelemek üzere sürü etkileşiminin dahil edilmesi ve ihmal edilmesi durumları için bakteri sayısı $S_{b}=40$, kemotaksis sayısı $N_{c}=50$, yüzme sayısı $N_{s}=100$, üreme sayısı $N_{r e}=20$ ve ortadan kaldırma-yeniden dağılma sayısı $N_{e d}=5$, başlangıç adım uzunluğu $C(i)_{0}=20.0$ olarak seçilmek suretiyle algoritma çalıştırılmıştır. Bu çalışmalar sonunda elde edilen bulgular bir sonraki bölümde verilmektedir.

\section{Bulgular}

Bakteri yiyecek arama optimizasyon algoritmasının parametre sayısının fazla olması nedeniyle herbir parametre için farklı değerlerin kombinasyonunun tamamı bir seferde değerlendirmesinin zorluğundan dolayı ikili etkilerin incelenmesi yolu tercih edilmiştir. Önceki bölümde parametrelerin hangi aralıklarda kullanıldı ̆̆ 
ilgili bilgiler paylaşılmıştır. Bu parametreler kullanılarak elde edilen bulgular alt bölümlerde verilmektedir.

Çalışmada yapı ağırlığının iterasyon sayısına göre değişiminin sunulduğu grafikler bulunmaktadır. $\mathrm{Bu}$ grafiklerde yer alan iterasyon sayısı kemotaksis sayısı, üreme sayısı ve ortadan kaldırma-yeniden dağılma sayıları çarpımı sonucu elde edilen sayı(iterasyon sayısı = $\left.N_{c} \times N_{r e} \times N_{e d}\right)$ olarak tarif edilmiştir. Yüzme sayısı iterasyon sayısının hesabı dışında tutulmuştur çünkü bazı durumlarda bakteri için belirlenen yönde besin olarak zayıf bir ortama geçilmesi halinde yüzme sayısı sıfır olurken bazı durumlarda bakterinin her adımında besin yönünden zengin ortama geçilmesi sebebiyle verilen yüzme sayısının sonuna kadar gidilebilir. Bu nedenle yüzme sayıları her döngüde farklılık gösterebilir.

\subsection{Kafes yapı örnekleri}

Bu çalışmada üç farklı kafes yapı ele alınmıştır. Birinci kafes yapı örneği birçok araştırmacı tarafından[12, 29-33] en hafif kafes yapı tasarımı optimizasyonu çalışmalarında test problemi olarak ele alınan on çubuklu düzlem kafes yapıdır. Kafes yapının geometrisi Şekil 1'de verilmektedir. Düzlem kafes yapının çubukları $\pm 172.37 \mathrm{MPa}$ gerilme ile düğüm noktası deplasmanları ise $\pm 5.08 \mathrm{~cm}$ ile sınırlandırılmıştır. Elastisite modülü $E=68947.57 \mathrm{MPa}$ ve malzeme birim hacim ağırlı̆̆ $\rho=2767.99 \mathrm{~kg} / \mathrm{m}^{3}$ 'tür. Kafes yapı üzerinde 2 ve 4 numaralı düğümlerde düşey yönde $667.23 \mathrm{kN}, 1$ ve 3 numaralı düğümlerde ise yine düşey yönde $222.41 \mathrm{kN}$ kuvvet uygulanmıştır.

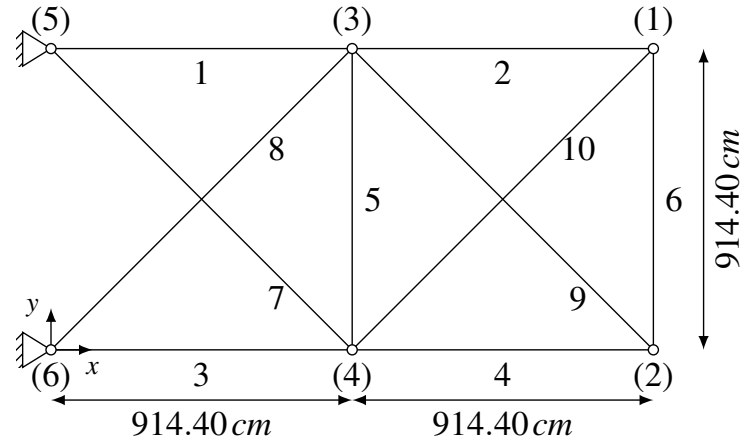

Şekil 1. 10 çubuklu düzlem kafes yapı

İkinci örnek problem de bir çok araştırmacı[12, 29-34] tarafindan optimizasyon problemlerinde test örneği olarak kullanılmıştır. Yirmi beş çubuklu uzay kafes yapının geometrisi Şekil 2'de verilmektedir. Kafes yapıda kullanılan malzemenin elastisite modülü $E=68947.57 \mathrm{MPa}$ ve birim hacim ă̆ırlı̆̆ $\rho=$ $2767.99 \mathrm{~kg} / \mathrm{m}^{3}$ 'tür. Çubuk elemanlarda kullanılan gerilme limitleri ve çubukların bulunduğu grup bilgileri Tablo 1'de verilmektedir. Deplasman limitleri tüm dügüumler için $\mp 0.89 \mathrm{~cm}$ 'dir. Kesit alanları alt limiti $0.06 \mathrm{~cm}^{2}$ olarak verilmiştir. Kafes yapı iki yükleme durumunda zorlanmakta olup etki eden kuvvetler Tablo 2'de verilmektedir.

Kafes yapı optimizasyonunda kullanılan bir başka test problemi olan 72 çubuklu uzay kafes yapının geometrisi Şekil 3'de verildiği gibidir. Kafes yapının çubukları üzerinde $\pm 172.37 \mathrm{MPa}$ gerilme limiti ve
Tablo 1. 25 çubuklu uzay kafes yapı çubuklarının bağ olduğu grup bilgileri ve gerilme limitleri

\begin{tabular}{ccrc}
\hline Grup No. & $\begin{array}{l}\text { Grupta } \\
\text { bulunan } \\
\text { çubuklar }\end{array}$ & $\begin{array}{c}\text { Basinç } \\
\text { gerilme } \\
\text { limiti } \\
(\mathrm{MPa})\end{array}$ & $\begin{array}{c}\text { Çekme } \\
\text { gerilme } \\
\text { limiti } \\
(\mathrm{MPa})\end{array}$ \\
\hline 1 & $A_{1}$ & 241.95 & 275.79 \\
2 & $A_{2} \sim A_{5}$ & 79.91 & 275.79 \\
3 & $A_{6} \sim A_{9}$ & 119.31 & 275.79 \\
4 & $A_{10} \sim A_{11}$ & 241.95 & 275.79 \\
5 & $A_{12} \sim A_{13}$ & 241.95 & 275.79 \\
6 & $A_{14} \sim A_{17}$ & 46.60 & 275.79 \\
7 & $A_{18} \sim A_{21}$ & 46.60 & 275.79 \\
8 & $A_{22} \sim A_{25}$ & 76.41 & 275.79 \\
\hline
\end{tabular}

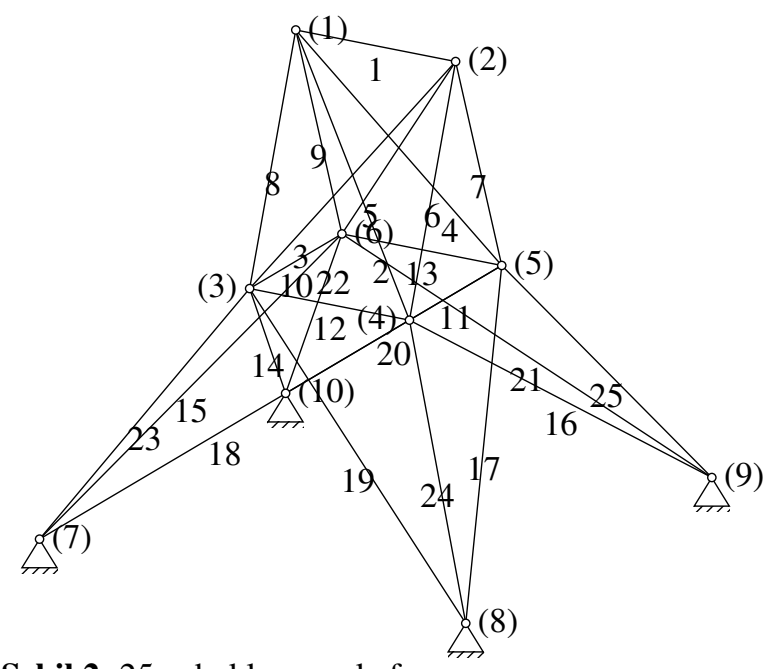

Şekil 2. 25 çubuklu uzay kafes yapı

Tablo 2. 25 çubuklu uzay kafes yapıya etki eden yükler

\begin{tabular}{cccrr}
\hline & Dügüum No. & $\begin{array}{c}P_{x} \\
(\mathrm{kN})\end{array}$ & $\begin{array}{c}P_{y} \\
(\mathrm{kN})\end{array}$ & \multicolumn{1}{c}{$\begin{array}{c}P_{z} \\
(\mathrm{kN})\end{array}$} \\
\hline Yükleme & 1 & 0.00 & 88.96 & -22.24 \\
durumu I & 2 & 0.00 & -88.96 & -22.24 \\
& & & & \\
Yükleme & 1 & 0.00 & 44.48 & -22.24 \\
durumu II & 2 & 0.00 & 44.48 & -22.24 \\
& 3 & 2.22 & 0.00 & 0.00 \\
& 6 & 2.22 & -88.96 & 0.00 \\
\hline
\end{tabular}

düğüm noktalarında deplasman limiti $\pm 0.64 \mathrm{~cm}$ olarak uygulanmıştır. Kullanılan malzemenin elastisite modülü $E=68947.57 \mathrm{MPa}$ ve birim hacim ağırlı̆̆ $\rho=2767.99 \mathrm{~kg} / \mathrm{m}^{3}$ 'tür. Kafes yapı üzerinde iki yükleme durumu etki etmektedir. Birinci yükleme durumunda $17,18,19$ ve 20 numaralı düğüm noktalarında $22.24 \mathrm{kN}$ kuvvet düşey yönde etki etmektedir. İkinci yükleme durumunda ise 17 numaralı düğüm noktasında pozitif $\mathrm{x}$ ve y yönlerinde $22.24 k N$ ve negatif z yönünde $22.24 k N$ büyüklüğünde kuvvet etki etmektedir. Kafes yapının elemanları 16 grupta toplanmıştır. Çubukların bağlı olduğu grup bilgileri Tablo 3'de verilmiştir. 
Tablo 3. 72 çubuklu uzay kafes yapının çubukların bağ olduğu grup bilgileri

\begin{tabular}{cccl}
\hline Grup No. & $\begin{array}{l}\text { Grupta } \\
\text { bulunan } \\
\text { çubuklar }\end{array}$ & Grup No. & $\begin{array}{l}\text { Grupta } \\
\text { bulunan } \\
\text { çubuklar }\end{array}$ \\
\hline 1 & $A_{1} \sim A_{4}$ & 9 & $A_{37} \sim A_{40}$ \\
2 & $A_{5} \sim A_{12}$ & 10 & $A_{41} \sim A_{48}$ \\
3 & $A_{13} \sim A_{16}$ & 11 & $A_{49} \sim A_{52}$ \\
4 & $A_{17} \sim A_{18}$ & 12 & $A_{53} \sim A_{54}$ \\
5 & $A_{19} \sim A_{22}$ & 13 & $A_{55} \sim A_{58}$ \\
6 & $A_{23} \sim A_{30}$ & 14 & $A_{59} \sim A_{66}$ \\
7 & $A_{31} \sim A_{34}$ & 15 & $A_{67} \sim A_{70}$ \\
8 & $A_{35} \sim A_{36}$ & 16 & $A_{71} \sim A_{72}$ \\
\hline
\end{tabular}
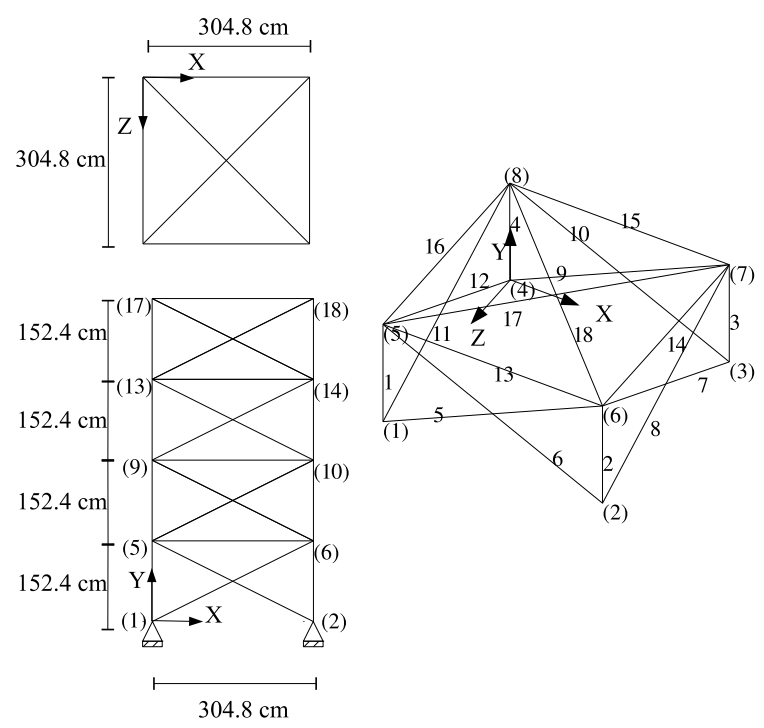

Şekil 3. 72 çubuklu uzay kafes yapı

\subsection{Adım uzunluğunun ve yüzme sayısının etkileri}

Yüzme sayısı ve adım uzunluğu parametrelerinin etkilerini gözleyebilmek için farklı adım uzunlukları için yüzme sayısı 10, 100 ve 1000 seçilmesi durumunda iterasyon sayısına karşılık yapı ağırlığının değişimi on çubuklu düzlem kafes problemi için Şekil 4'da yirmi beş çubuklu uzay kafes problemi için ise Şekil 5'de verilmiştir. Burada uygulanan adım uzunlukları büyükten küçüğe şöyle siralanmıştır: 20, 2, 0.5, 0.1, 0.05, 0.01 .

On çubuklu düzlem kafes yapı problemi için Şekil 4 incelendiğinde adım uzunluğunun 20.0 ve 2.0 olması durumunda yüzme sayısının etkili olmadığ $\breve{1}, C(i)=0.5$ için yüzme sayısı $N_{s}=10$ olması durumunda çok az bir farkın olduğu gözlenmektedir. Adım uzunluğunun $C(i)=0.1$ olması halinde $N_{s}=10$ için yaklaşım hızının oldukça değiştiği gözlenmektedir. Adım uzunluğunun küçülmesiyle birlikte yüzme sayılarının önemli hale geldiği anlaşılmaktadır. Bu durum adım uzunluğu 0.01 olduğu durumda Şekil 4.f'de açıkça görülmektedir(f durumu için çizgi bilgilendirmesi diğer beş durum ile aynıdır). Yüzme sayısının 10 olması halinde yaklaşım hızının oldukça düştüğü 100 ve 1000 olması durumunda adım uzunluğu 0.01 dışında çok büyük değişimlerin olmadığı Şekil 4'den anlaşılmaktadır. Yüzme sayısı 100 ve 1000 için adım uzunluğunun büyük olması durumunda elde edilen yapı ağırlıkları görece olarak daha ağır kalmaktadır. Dikkat çeken diğer bir durum adım uzunluğunun büyük olması durumunda elde edilen yapı ağırlıklarının daha fazla olduğudur. Adım uzunluğunun küçülmesiyle birlikte daha hafif yapı ağırlıkları elde edilebilmektedir.

Yirmi beş çubuklu uzay kafes problemi için adım uzunluğu ve yüzme sayılarının farklı değerler alması durumunda iterasyon sayısına bağlı olarak yapı ağırlığının değişimleri Şekil 5'de verilmektedir. On çubuklu düzlem kafes yapı problemine benzer olarak adım uzunluğunun büyük olması durumunda algoritmadan elde edilen yapı ağırlıkları fazla olmaktadır. Özellikle adım uzunluğu $C(i)=20.0$ için elde edilen sonuçların optimum olarak değerlendirilmesi kabul edilebilir sınırların dışında kalmaktadır. Bu örnek problemde adım uzunluğunun $C(i)=0.01$ değeri dışında yüzme sayılarının elde edilen sonuçlara etki etmediği görülmektedir. Adım uzunluğunu 0.01 olması durumunda yüzme sayısı 10 olarak kullanılmak suretiyle algoritma çalıştırıldığında yaklaşım hızının oldukça yavaş ve elde edilen yapı ağırlığının da fazla olduğu gözlenmektedir.

Tablo 4'de on çubuklu düzlem kafes yapı problemi ve Tablo 5'de yirmi beș çubuklu uzay kafes yapı problemi için adım uzunluğu $C=20,2,1,0.5,0.1,0.05,0.01, S_{b}=$ $40, N_{s}=10,100,1000, N_{c}=20, N_{r e}=20$ ve $N_{e d}=5$ parametre değerleri kullanılarak 30 farklı analiz sonunda elde edilen en iyi, en kötü ve ortalama yapı ağırlığı değerleri ve bu değerleri elde etmek için gerçekleştirilen yapı analizi sayıları verilmiştir. Bunlara ek olarak aynı tablolarda 30 farklı analizin standart sapması ve varyasyon katsayıs1 \% olarak verilmiştir. Bu tablolar incelendiğinde adım uzunluğunun büyük olduğu durumlarda elde edilen yapı ağırlıklarının görece fazla olduğu ancak yapı analizi sayılarının daha az olduğu görülmektedir. Tablo 4'de ortalama en hafif yapı ağırlığ ${ }_{1} 20849.0 \mathrm{~N}$ olarak adım uzunluğu 0.5 , yüzme sayısı 10 olduğu durumda elde edilmiştir. $C(i)=0.5, N_{s}=10$ için gerçekleştirilen yapı analizi sayılarının da nispeten az olduğu görülmektedir. Ancak aynı tablo incelendiğinde farklı adım uzunlukları için yüzme sayısı 10 olması durumunda standart sapma ve varyasyon katsayısı değerlerinin bazılarının oldukça büyük olduğu göze çarpmaktadır. Tablonun geneline bakıldığında farklı adım uzunluklarında varyasyon katsayısı değeri değişmekle beraber yüzme sayısı 10 olması durumunda en büyük varyasyon katsayısı değerleri ile karşılaşılmaktadır. $\mathrm{Bu}$ durumun her iki örnek için de geçerli olduğu görülmektedir. Varyasyon katsayısının büyüklüğü algoritmanın her bağımsız çalışması sonunda elde edilen değerlerin birbirinden uzaklığının ölçütü olduğuna göre yüzme sayısı 10 için algoritmanın diğer yüzme sayısı değerlerine nazaran daha az kararlı davrandığ 1 sonucu ortaya çıkmaktadır. Bunun yanında adım uzunlukları 20.0, 2.0, 0.5, 0.1, 0.05 ve 0.01 değerlerinin herbirinde varyasyon katsayısı açısından oldukça farklı değerlere rastlanmaktadır. Bu bulgu adım uzunluğunun elde edilecek sonuca etki ettiğini açıç̧a göstermektedir. 


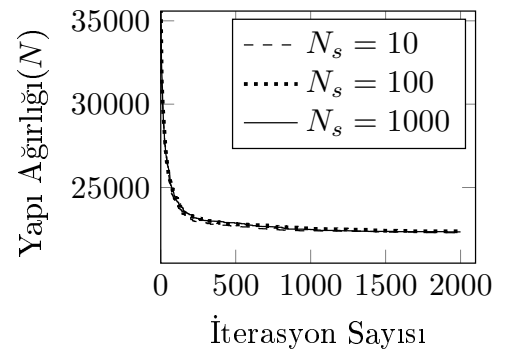

(a) $C(i)=20.0$

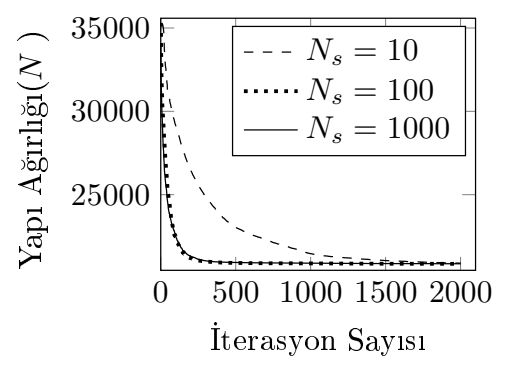

(d) $C(i)=0.1$

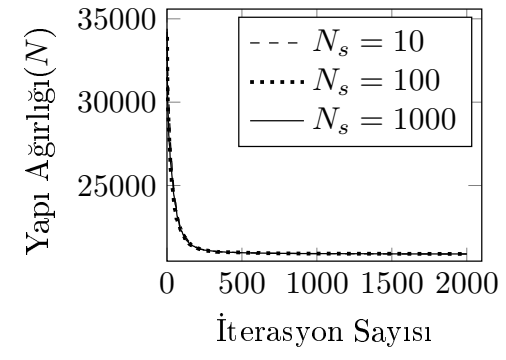

(b) $C(i)=2.0$

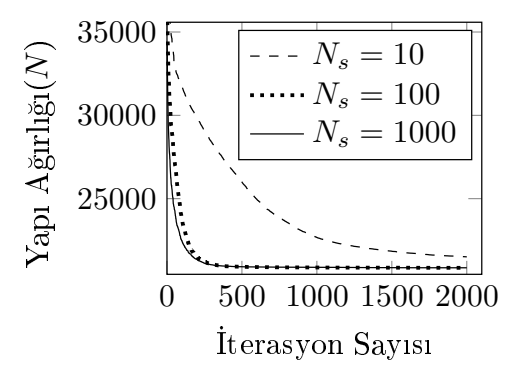

(e) $C(i)=0.05$

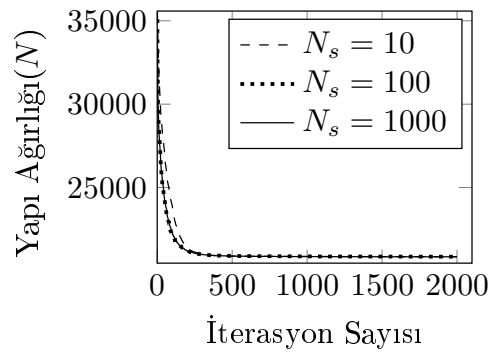

(c) $C(i)=0.5$

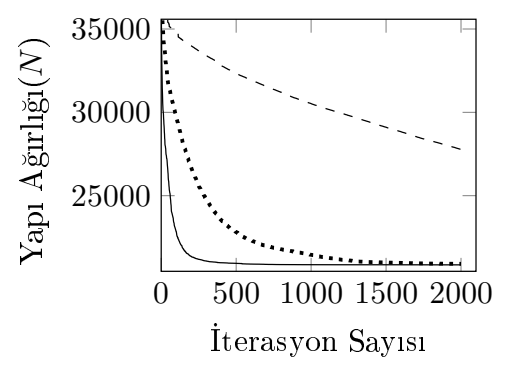

(f) $C(i)=0.01$

Şekil 4. On çubuklu düzlem kafes probleminde farklı $N_{s}$ ve $C(i)$ değerleri için BFO algoritmasının yaklaşım hızı

Tablo 4. 10 çubuklu düzlem kafes yapı optimum analiz istatistik değerleri

\begin{tabular}{rrrrrrrrrr}
\hline \multirow{2}{c}{$C(i)$} & $N_{s}$ & En iyi & Ortalama & En kötü & En iyi & Ortalama & En kötü & Std Sapma & $V_{k}(\%)$ \\
\hline \multirow{2}{*}{20.0} & 10 & 21567.8 & 22287.0 & 22772.8 & 27478 & 28631 & 30763 & 59.75 & 1.19 \\
& 100 & 21854.1 & 22364.0 & 23072.7 & 28456 & 28668 & 28859 & 68.45 & 1.36 \\
& 1000 & 21834.7 & 22337.2 & 22808.1 & 26575 & 28734 & 27960 & 54.60 & 1.09 \\
2.0 & 10 & 20844.1 & 20889.0 & 20967.7 & 32424 & 32071 & 31302 & 6.99 & 0.15 \\
& 100 & 20823.4 & 20894.5 & 20976.1 & 32986 & 32497 & 32908 & 7.14 & 0.15 \\
& 1000 & 20836.0 & 20894.0 & 21022.7 & 32281 & 32431 & 33016 & 7.22 & 0.15 \\
0.5 & 10 & 20813.4 & 20849.0 & 20919.1 & 39428 & 38874 & 38701 & 5.92 & 0.13 \\
& 100 & 20811.6 & 20849.2 & 20920.0 & 44829 & 45168 & 46673 & 5.37 & 0.11 \\
& 1000 & 20813.1 & 20842.5 & 20928.0 & 44597 & 45297 & 44283 & 4.56 & 0.10 \\
0.1 & 10 & 20806.5 & 20891.6 & 21076.5 & 62751 & 60750 & 56319 & 16.71 & 0.36 \\
& 100 & 20811.0 & 20851.2 & 20943.8 & 90425 & 95393 & 95490 & 7.34 & 0.16 \\
& 1000 & 20811.1 & 20854.7 & 20971.5 & 114793 & 115022 & 117951 & 7.49 & 0.16 \\
0.05 & 10 & 20811.8 & 21511.4 & 23865.4 & 70742 & 86139 & 88340 & 218.56 & 4.52 \\
& 100 & 20806.6 & 20851.5 & 20904.8 & 133292 & 136386 & 141294 & 5.86 & 0.12 \\
& 1000 & 20806.5 & 20854.3 & 20932.7 & 194559 & 199919 & 206766 & 7.09 & 0.15 \\
0.01 & 10 & 23140.9 & 27783.7 & 33227.7 & 198044 & 186190 & 162397 & 537.29 & 8.60 \\
& 100 & 20811.1 & 20914.1 & 21396.2 & 389440 & 348896 & 403056 & 27.17 & 0.58 \\
& 1000 & 20810.0 & 20849.7 & 21017.4 & 653866 & 699463 & 703577 & 8.92 & 0.19 \\
değgiskken & 10 & 20831.4 & 20946.4 & 21233.3 & 43759 & 43270 & 39618 & 21.93 & 0.47 \\
& 100 & 20812.7 & 20904.2 & 21056.3 & 58378 & 53460 & 44733 & 14.06 & 0.30 \\
& 1000 & 20808.3 & 20865.8 & 20981.3 & 47322 & 79695 & 49389 & 8.74 & 0.19 \\
\hline
\end{tabular}

\subsection{Adım uzunluğu stratejisinin etkileri}

Sabit adım uzunluğu kullanılması ve değişken adım uzunluğu kullanılması durumunda yapı ağırlığının iterasyon sayısı ile değişimi on çubuklu düzlem kafes yapı problemi için Şekil 6'de, yirmi beş çubuklu uzay kafes yapı problemi için ise Şekil 7'da verilmiştir.

On çubuklu düzlem kafes yapı örneğinde adım uzunluğu $C(i) \in\{20.0,2.0,0.5,0.1,0.05,0.01\}$ değerlerinde sabit tutulmak üzere 6 farklı adım uzunluğu için BFO algoritması çalıştırılmıştır. Her adım uzunluğu için 30 bağımsız çalışma gerçekleştirilmiş olup Şekil 6'da elde edilen 30 değerin ortalamasının değişimleri yer almaktadır. Adım uzunluğu $C(i)=$ değişken olarak tarif edilen durumda ise başlangıç adım uzunluğu $C(i)_{0}=20.0$ olan ancak her üreme iterasyonunda adım uzunluğunun yarıya düşürülmesi ile elde edilen yapı ağırlığı değişimleri yer almaktadır. 5000 iterasyon sonunda elde edilen ortalama en hafif yapı adım uzunluğu 0.01 olması durumunda $20871.0 N$ ve ortalama yapı analizi sayıs 519125 olarak elde edilmiştir. Adım uzunluğunun değişken olması halinde ise elde edilen ortalama yapı ağırlığ $20843.6 N$ ve yap1 analizi sayısı 79215 olmuştur. Adım uzunluğunun değişken olması durumu ile 0.01 olarak sabit tutulması 


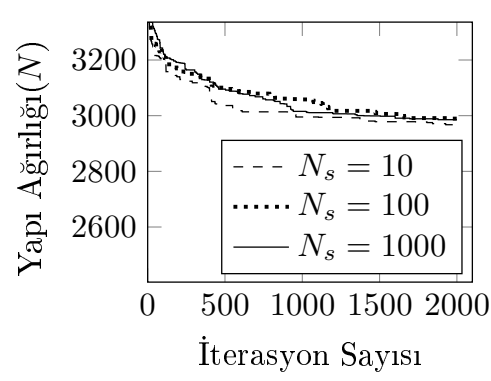

(a) $C(i)=20.0$

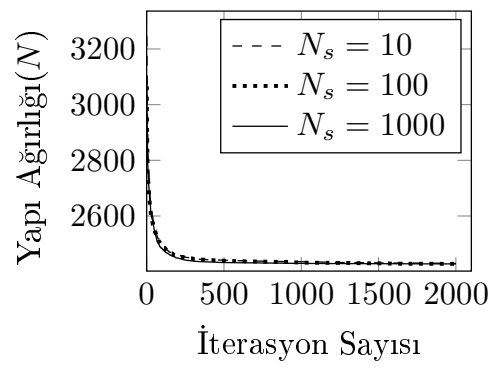

(d) $C(i)=0.1$

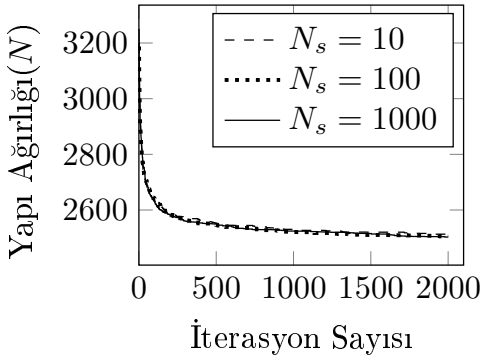

(b) $C(i)=2.0$

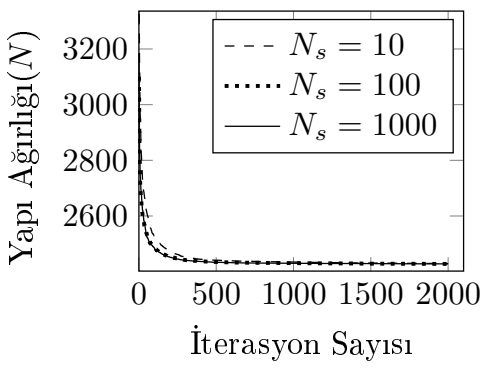

(e) $C(i)=0.05$

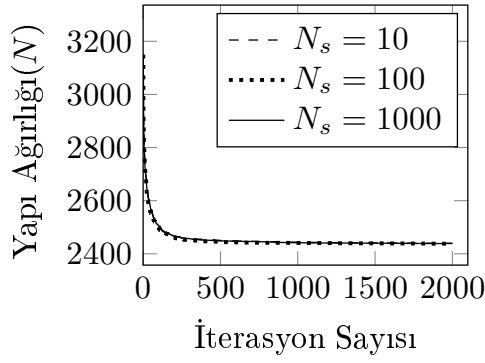

(c) $C(i)=0.5$

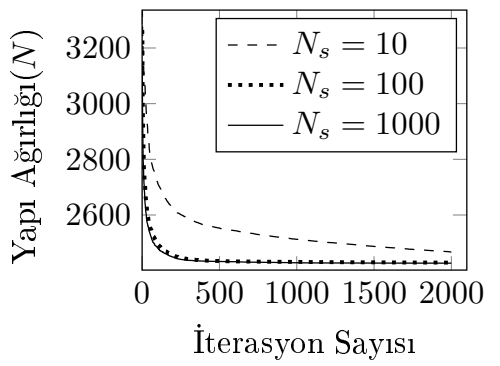

(f) $C(i)=0.01$

Şekil 5. Yirmi beş çubuklu uzaykafes probleminde farklı $N_{s}$ ve $C(i)$ değerleri için BFO algoritmasının yaklaşım hızı

Tablo 5. 25 çubuklu uzay kafes yapı optimum analiz istatistik değerleri

\begin{tabular}{|c|c|c|c|c|c|c|c|c|c|}
\hline \multirow[b]{2}{*}{$C(i)$} & \multicolumn{4}{|c|}{ Yap1 A $\breve{g}_{1} \operatorname{rl}_{1} \breve{g}_{1}(N)$} & \multicolumn{3}{|c|}{ Yapı Analizi Sayısı } & \multirow[b]{2}{*}{ Std Sapma } & \multirow[b]{2}{*}{$V_{k}(\%)$} \\
\hline & $N_{s}$ & En iyi & Ortalama & En kötü & En iyi & Ortalama & En kötü & & \\
\hline \multirow{3}{*}{20.0} & 10 & 2621.9 & 2967.5 & 3212.0 & 44250 & 54995 & 59791 & 29.97 & 4.49 \\
\hline & 100 & 2805.0 & 2989.5 & 3161.4 & 55561 & 56152 & 59918 & 20.27 & 3.02 \\
\hline & 1000 & 2764.7 & 2985.6 & 3159.7 & 52035 & 55988 & 59424 & 21.58 & 3.22 \\
\hline \multirow{3}{*}{2.0} & 10 & 2440.7 & 2513.2 & 2602.8 & 38591 & 40822 & 40021 & 7.79 & 1.38 \\
\hline & 100 & 2475.7 & 2505.1 & 2561.4 & 40072 & 40684 & 40337 & 4.24 & 0.75 \\
\hline & 1000 & 2451.5 & 2502.2 & 2558.5 & 40434 & 40728 & 42216 & 5.40 & 0.96 \\
\hline \multirow{3}{*}{0.5} & 10 & 2431.5 & 2440.0 & 2459.6 & 39520 & 39495 & 39869 & 1.18 & 0.22 \\
\hline & 100 & 2428.8 & 2437.9 & 2446.1 & 39555 & 39548 & 39388 & 0.83 & 0.15 \\
\hline & 1000 & 2433.7 & 2438.7 & 2446.1 & 39181 & 39624 & 39765 & 0.78 & 0.14 \\
\hline \multirow{3}{*}{0.1} & 10 & 2425.8 & 2429.4 & 2467.1 & 42981 & 43441 & 43811 & 1.81 & 0.33 \\
\hline & 100 & 2425.9 & 2428.0 & 2443.6 & 45259 & 45988 & 46738 & 0.71 & 0.13 \\
\hline & 1000 & 2425.9 & 2427.9 & 2440.2 & 46405 & 46312 & 45928 & 0.57 & 0.10 \\
\hline \multirow{3}{*}{0.05} & 10 & 2425.5 & 2429.3 & 2493.5 & 47420 & 46444 & 46260 & 2.74 & 0.50 \\
\hline & 100 & 2425.7 & 2427.8 & 2448.0 & 52336 & 53794 & 54755 & 1.18 & 0.22 \\
\hline & 1000 & 2425.5 & 2428.0 & 2455.9 & 57010 & 55397 & 58128 & 1.41 & 0.26 \\
\hline \multirow{3}{*}{0.01} & 10 & 2425.3 & 2466.9 & 2596.9 & 63503 & 60599 & 61810 & 8.15 & 1.47 \\
\hline & 100 & 2425.1 & 2428.9 & 2462.4 & 98683 & 95134 & 92040 & 1.92 & 0.35 \\
\hline & 1000 & 2425.2 & 2426.9 & 2450.5 & 109848 & 119289 & 121009 & 1.01 & 0.19 \\
\hline \multirow{3}{*}{ değişken } & 10 & 2425.2 & 2429.8 & 2485.7 & 42308 & 43388 & 44655 & 2.56 & 0.47 \\
\hline & 100 & 2425.0 & 2426.7 & 2431.9 & 44561 & 44978 & 43558 & 0.41 & 0.07 \\
\hline & 1000 & 2425.0 & 2427.4 & 2444.9 & 47229 & 47350 & 51418 & 0.82 & 0.15 \\
\hline
\end{tabular}

halinde iki çözüm arasında ortalama yapı ağırlığı farkının \%0.13 kadar olmaktadır. Adım uzunluğu değişken olduğu durumda yapı ağırlı̆̆ı daha hafif olmaktadır. Bunun yanında gerekli ortalama yapı analizi sayısı sabit adım uzunluğu kullanılması durumunda değişken olması durumuna göre 6.5 katı kadar olmaktadır.

Yirmi beş çubuklu uzay kafes örneğinde de adım uzunlukları on çubuklu düzlem kafes yapı örneğinde olduğu gibi kullanılmıştır. Ancak adım uzunluğunun 20.0 ve 2.0 olması durumunda elde edilen ortalama yapı ağırlıkları 2446.5N'nin üzerinde olduğundan Şekil 7'de bu büyüklükler kullanılarak elde edilen sonuçlara yer verilmemiştir. Yirmi beş çubuklu uzay kafes yap1 örneğinde adım uzunluğunun 0.01 olarak sabit tutulması durumunda ortalama yapı ağırlığı $2425.7 N$ ve gerçekleştirilen yapı analizi sayısı 174090 kadar olmuştur. Adım uzunluğunun değişken tutulması durumunda elde edilen yap1 a $\breve{g} 1 r l ı \breve{g} 12425.8 N$ ve gerçekleştirilen yap1 analizi sayısı da 101182 olmuştur. İki çözüm arasındaki ortalama yapı ağırlı̆̆ farkının \%0.007 kadar olduğu görülmektedir. Adım uzunluğu 0.01 için ortalama yapı ağırlığı çok az da olsa daha hafif olmasına rağmen ortalama 
yapı analizi sayısı yaklaşık 1.7 katı kadar olmaktadır.

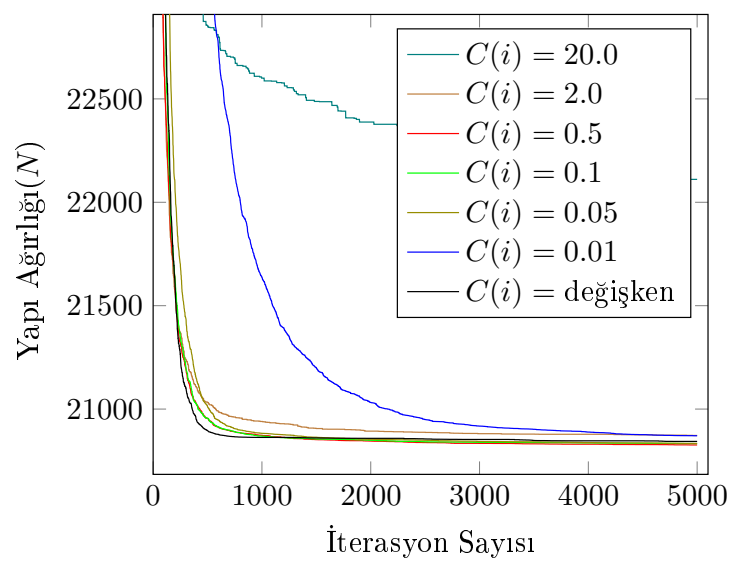

Şekil 6. On çubuklu düzlem kafes yapının farklı $C(i)$ değerleri için BFO algoritmasından elde edilen ortalama yapı ağırlı̆̆ı değişimleri

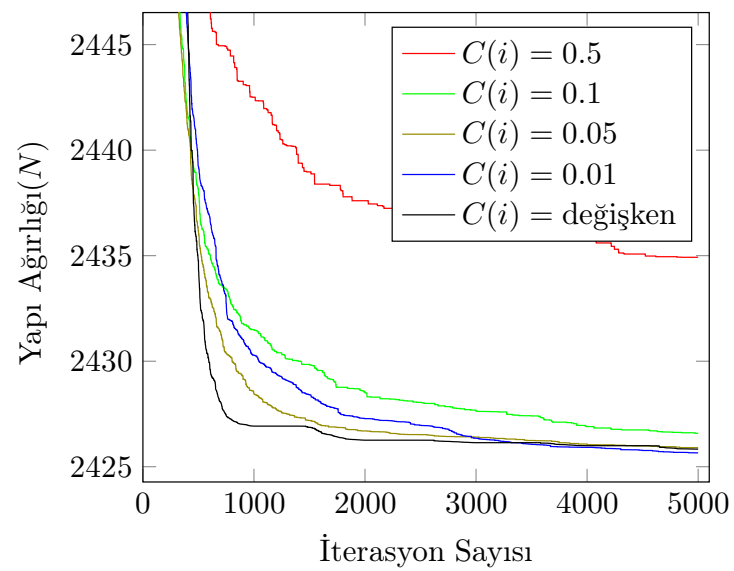

Şekil 7. Yirmi beş çubuklu uzay kafes yapının farklı $C(i)$ değerleri için BFO algoritmasından elde edilen ortalama yap1 ağırlı̆̆ı değişimleri

\subsection{Bakteri sayısı ve kemotaksis sayısının etkisi}

Şekil 8'de on çubuklu düzlem kafes yapının ve Şekil 9'da yirmi beş çubuklu uzay kafes yapının, farklı bakteri sayısı ve farklı kemotaksis sayıları kullanılması durumunda elde edilen ortalama yapı ağırlığı değişimleri verilmektedir. Bakteri sayısının 20 olması durumunda belirgin biçimde her iki örnek problemde de yapı ağırlığının daha ağır elde edildiği görülmektedir. Bakteri sayısının 40, 60, 80 ve 100 olması durumlarında yapı ağırlıklarının birbirine yakın olduğu anlaşılmakla birlikte kemotaksis sayısının artmasıyla beraber elde edilen yapı ağırlıklarının da birbirine daha fazla yaklaştığg gözlenmektedir. On çubuklu düzlem kafes yapı probleminde kemotaksis sayısının 50 ve daha büyük olması halinde gerçekleştirilen optimizasyon sonucu elde edilen yapı ağırlıkları pek de farklı değildir. Yirmi beş çubuklu uzay kafes yapı probleminde ise kemotaksis sayıs1 40 ve daha büyük olması durumunda benzer durum ile karşılaşılmaktadır.

Şekil 10 ve Şekil 11'de sırasıyla on çubuklu düzlem kafes yapının ve yirmi beş çubuklu uzay kafes yapının farklı bakteri sayısı ve kemotaksis sayısı değerleri kullanılarak

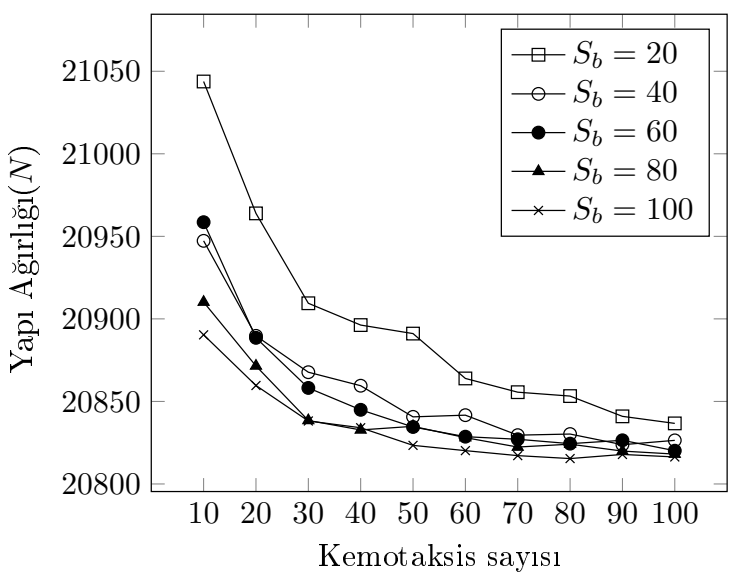

Şekil 8. On çubuklu düzlem kafes yapının farklı $S_{b}$ ve $N_{c}$ değerleri için BFO algoritmasından elde edilen ortalama yapı ağırlı̆̆ değişimleri

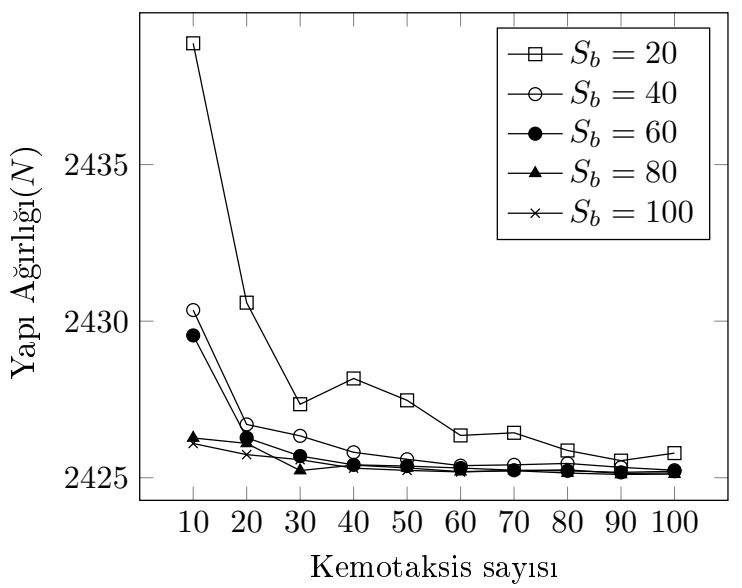

Şekil 9. Yirmi beş çubuklu uzay kafes yapının farklı $S_{b}$ ve $N_{c}$ değerleri için BFO algoritmasından elde edilen ortalama yapı ağırlığı değişimleri

elde edilen varyasyon katsatyısı değişimleri verilmektedir. Her iki örnek problem için de elde edilen sonuçların varyasyon katsayılarının tamamının \%0.8' in altında olduğu gözlenmektedir. Bu durum algoritmanın oldukça kararlı sonuçlar ürettiğinin bir göstergesidir. Bakteri sayısının 20 olması durumunda her iki örnek problemde yap1 ağırlığı karşılaştırmasında olduğu gibi varyasyon katsatyısı karşılaştırmasında da diğer koloni sayısı değerlerinden açıkça daha ağır ve saçılımın daha fazla olduğu değerler elde edilmektedir. On çubuklu düzlem kafes yap1 probleminde kemotaksis sayısı 50 ve daha fazla olması durumunda bakteri sayısı 40, 60, 80 ve 100 için varyasyon katsayısının çok farklı olmadı̆̆ 1 bahsi geçen koloni sayılarında \%0.1 veya daha altında olduğu gözlenmektedir. Yirmi beş çubuklu uzay kafes probleminde ise kemotaksis sayıs 40 ve daha fazla olmasi durumunda bakteri sayısı 20 dışındaki durumlarda \%0.05 civarında olduğu görülmektedir. Varyasyon katsayısının bu derece küçük olması algoritmada kullanılan parametrelerin oldukça kararlı sonuçlar üretilmesini sağladığını göstermektedir.

Yapılan karşılaştırmalar sonunda bakteri sayısının 20 olması durumunda varyasyon katsayısı değerleri tatmin edici olsa da elde edilen yapı ağırlığı değerlerinin memnuyiet verici olmadı̆̆ı söylenebilir. Ancak 
mühendislik açısından bakıldığında on çubuklu düzlem kafes yap1 örneğinde bakteri sayısı 20 için elde edilen yapı ağırlıkları diğer koloni sayıları ile karşılaştırıldığında oldukça az sayıda yapı analizi gerçekleştirilerek elde edilmiş sonuçlardır. Kemotaksis sayısı 50 için elde edilen değerler baz alınarak bakteri sayısı 20 ve diğer koloni sayıları kullanılarak elde edilen sonuçlar karşılaştırılırsa yaklaşık olarak \%0.34 kadar daha ağır olduğu anlaşılmaktadır. Aynı şartlarda yirmi beş çubuklu uzay kafes yapı probleminde bu fark \%0.11 civarındadır. Yapı ağırlıkları arasındaki bu fark ele alınan problemin hassasiyetine göre değişiklik gösterebilirse de (daha hızlı sonuç alınmak istenirse) bazı durumlarda önemli görülmeyebilir. Daha hassas sonuçların elde edilmesi istenmesi halinde ise bakteri sayısının 40 civarında seçilmesi yeterli olabilecektir. Koloni sayısının 40'1n üstünde tercih edilmesi durumunda her iki örnek problemde hassasiyette bir artışın elde edilebileceğini göstermekle birlikte gerekli yapı analizi sayılarında da büyük artışlar meydana gelecektir. Ancak elde edilecek sonuçların daha az bakteri kullanılarak (40 civarında) elde edilen sonuçlardan çok da farklı olmayacağı görülmektedir.

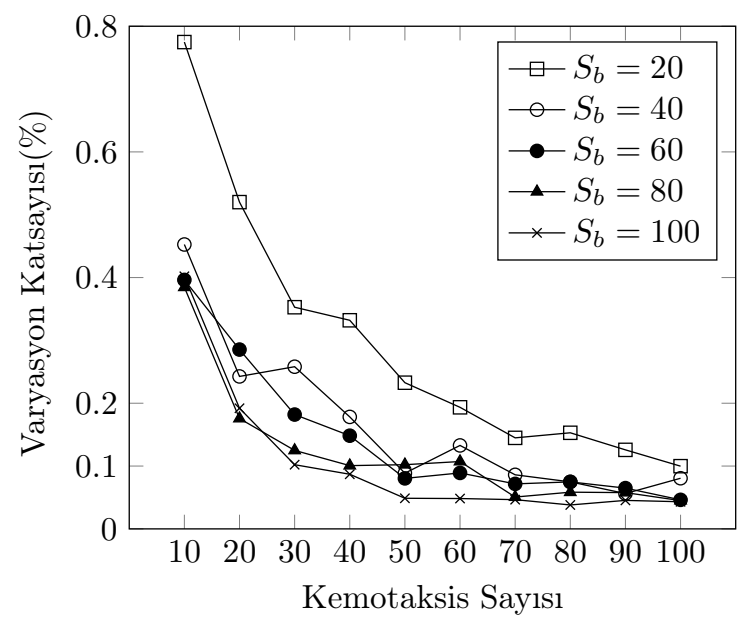

Şekil 10. On çubuklu düzlem kafes yapının farklı $S_{b}$ ve $N_{c}$ değerleri için BFO algoritmasından elde edilen varyasyon katsayı değişimleri

\section{5. Üreme sayısı ve ortadan kaldırma-yeniden dağılma sayısının etkisi}

Farklı üreme sayıları $\left(N_{r e} \in\{5,10,20\}\right)$ ve farklı ortadan kaldırma-yeniden dağılma $\operatorname{say} 1$ ları $\left(N_{e d} \in\{2,5,10\}\right)$ kullanılarak on çubuklu düzlem kafes yapı ve yirmi beş çubuklu uzay kafes yapının BFO algoritmasından elde edilen sonuçları sirasıyla Tablo 6 ve Tablo 7'de verilmiştir. Bahsi geçen tablolarda ilk kolon üreme sayılarını, ikinci kolon ortadan kaldırma-yeniden dağılma sayılarını göstermektedir. Algoritma 30 defa bağımsız olarak çalıştırılmış olup bu 30 farklı çalıştırma sonunda elde edilen yapı ağırlıklarının ortalaması üçüncü kolonda, ortalama yapı analizi sayısı ise dördüncü kolonda verilmektedir. Otuz farklı çalıştırmanın standart sapması ve varyasyon katsayısı da beşinci ve altıncı kolonlarda verilmiştir.

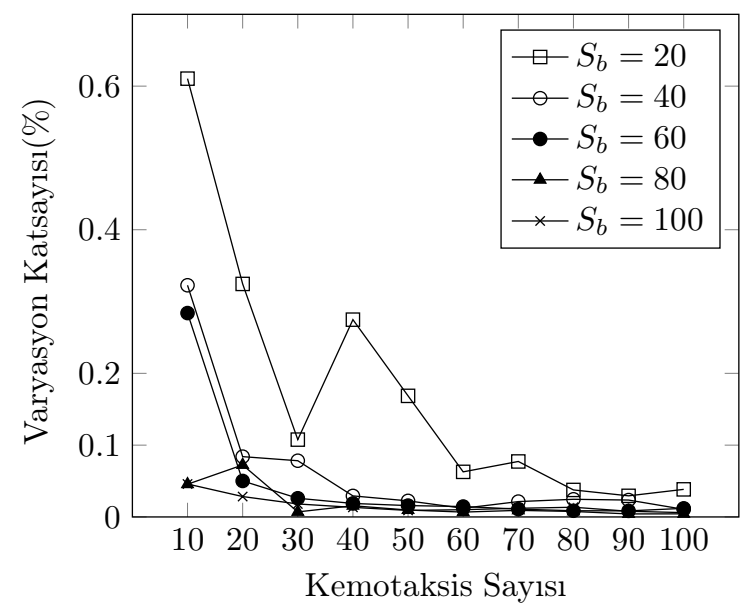

Şekil 11. Yirmi beş çubuklu uzay kafes yapının farklı $S_{b}$ ve $N_{c}$ değerleri için BFO algoritmasından elde edilen varyasyon katsayı değişimleri

Tablo 6. 10 çubuklu düzlem kafes yapı için farklı $N_{r e}$ ve $N_{e d}$ değerleri için elde edilen istatistik değerleri

\begin{tabular}{|c|c|c|c|c|c|}
\hline$N_{r e}$ & $N_{e d}$ & $\begin{array}{l}\text { Ortalama } \\
\text { Yap1 } \\
\text { A } \breve{g}_{1} \operatorname{rl}_{1} \breve{g}_{1}(N)\end{array}$ & $\begin{array}{c}\text { Ortalama } \\
\text { Analiz } \\
\text { Sayıs1 }\end{array}$ & $\begin{array}{c}\text { Std } \\
\text { Sapma }\end{array}$ & $V_{k}(\%)$ \\
\hline 5 & 2 & 21052.8 & 9101 & 21.77 & 0.46 \\
\hline 10 & 2 & 20859.5 & 16908 & 10.17 & 0.22 \\
\hline 20 & 2 & 20854.9 & 37865 & 6.89 & 0.15 \\
\hline 5 & 5 & 20938.7 & 19698 & 13.65 & 0.29 \\
\hline 10 & 5 & 20858.2 & 37471 & 8.33 & 0.18 \\
\hline 20 & 5 & 20843.4 & 79444 & 5.69 & 0.12 \\
\hline 5 & 10 & 20890.6 & 37137 & 5.20 & 0.11 \\
\hline 10 & 10 & 20846.8 & 71590 & 7.66 & 0.16 \\
\hline 20 & 10 & 20835.4 & 148122 & 4.08 & 0.09 \\
\hline
\end{tabular}

Tablo 7. 25 çubuklu uzay kafes yapı için farklı $N_{r e}$ ve $N_{e d}$ değerleri için elde edilen istatistik değerleri

\begin{tabular}{rrcccc}
\hline$N_{r e}$ & $N_{e d}$ & $\begin{array}{c}\text { Ortalama } \\
\text { Yap1 } \\
\text { A } ّ \text { Irlığ }(N)\end{array}$ & $\begin{array}{c}\text { Ortalama } \\
\text { Analiz } \\
\text { Say1s1 }\end{array}$ & $\begin{array}{c}\text { Std } \\
\text { Sapma }\end{array}$ & $V_{k}(\%)$ \\
\hline 5 & 2 & 2533.7 & 13257 & 6.85 & 1.20 \\
10 & 2 & 2429.5 & 22796 & 1.10 & 0.20 \\
20 & 2 & 2426.1 & 44575 & 0.57 & 0.10 \\
5 & 5 & 2509.6 & 29008 & 4.32 & 0.77 \\
10 & 5 & 2427.8 & 51741 & 0.77 & 0.14 \\
20 & 5 & 2425.7 & 101569 & 0.20 & 0.04 \\
5 & 10 & 2486.7 & 54883 & 4.76 & 0.85 \\
10 & 10 & 2426.5 & 99573 & 0.21 & 0.04 \\
20 & 10 & 2425.5 & 195265 & 0.10 & 0.02 \\
\hline
\end{tabular}

Üreme sayısı değerleri 5, 10 ve 20 için elde edilen sonuçlar incelendiğinde ortalama yapı ağırlı̆̆1 açısından en ağır yapıların üreme sayısı 5 olması durumunda ortaya çıktığ görülmektedir. Yapı analizi sayıları karşılaştırışdığında en az analiz sayılarının da üreme sayısı 5 olduğu durumda elde edildiği görülmektedir. Ancak üreme sayısının 5 olarak kullanılması halinde varyasyon katsayılarının 10 ve 20 olması durumlarına göre daha fazla olduğu görülmektedir. Üreme sayısının 10 olarak kullanılması durumunda yapı ağırlığı ve varyasyon katsayılarında belirgin bir azalma meydana gelmekle birlikte yap1 
analizi sayılarının da yaklaşık olarak iki katına çıktığı gözlenmektedir. Üreme sayısı 20 için elde edilen en hafif ortalama yapı ağırlıklarının ve en düşük değerli varyasyon katsayılarının elde edildiği görülmektedir. Bunun yanında en fazla ortalama yapı analizi sayıları üreme sayısı 20 olması durumunda ortaya çıktığı görülmektedir. Üreme sayısının arttıkça elde edilecek yapıların daha hafif olması ve gerekli yapı analizi sayılarının da fazla olması beklenen bir durumdur. Üreme sayıs 5 ile 20 olması durumunda gerekli yapı analizi sayıları yaklaşık olarak dört kat artarken yapı ağırlıklarındaki azalma on çubuklu düzlem kafes yapı probleminde $N_{r e}=2$ için $\% 0.9, N_{r e}=5$ için $\% 0.5, N_{r e}=10$ için $\% 0.3$, yirmi beş çubuklu uzay kafes yapı probleminde ise $N_{r e}=2$ için $\% 4.2, N_{r e}=5$ için $\% 3.3$, $N_{r e}=10$ için $\% 2.5$ olmaktadır. Her iki örnek problem için de üreme sayısı 20 ve ortadan kaldırma-yeniden dağılma sayısı 10 olması durumunda en hafif yapıların elde edildiği görülmektedir. Bunun yanında bahsi geçen değerler kullanılması durumunda varyasyon katsayısının da en az olduğu görülmektedir. Ancak en fazla yapı analizi sayıları da bu parametrelerle ortaya çıkmaktadır. Ancak üreme sayısı 20 ve ortadan kaldırma-yeniden dağılma sayısının 5 olarak kullanılması durumunda on çubuklu düzlem kafes yapı probleminde yapı analizi sayısı yaklaşı olarak yarıya düşerken ortalama yapı ağırlığındaki artış \%0.038 kadar olmaktadır. Yirmi beş çubuklu uzay kafes probleminde ise aynı parametreler için ortalama yapı analizi sayısı benzer şekilde yaklaşı olarak yarıya düşerken ortalama yapı ağırlığındaki artış \%0.008 kadar olmaktadır. Her iki problem için de yapı ağırlı̆̆ındaki artış miktarı mühendislik açısından önemsenmeyebileyecek düzeyde olurken yapı analizi sayılarında yarıya yakın azalmalar meydana gelmektedir. Bu sebeple çok hassas çözüm elde edilmesi gerekmediği durumlarda üreme sayısı 10 veya 20 seçilmesinin yeterli olacağı değerlendirilmektedir. Ortadan kaldırma-yeniden dağılma sayısının hızlı çözüm istenmesi halinde 2 olarak seçilmesi yeterli olabilecektir. Ancak hem hassasiyetin artması hem de nispeten hızlı çözüm elde edilmesi istenmesi halinde $N_{r e}=5$ olarak kullanılması uygun olacaktır.

\subsection{Sürü etkileşiminin etkisi}

Sürü etkileşiminin ihmal edilmesi ve dahil edilmesi durumunda iterasyon sayısına bağlı olarak yapı ağırlığı değişimleri on çubuklu düzlem kafes yapı için Şekil 12'de ve yirmi beş çubuklu uzay kafes için Şekil 13'de verilmiştir. Bahsi geçen grafikler BFO parametreleri $S_{b}=40, N_{c}=50$, $N_{s}=100, N_{r e}=20, N_{e d}=5$ ve adım uzunluğu değişken, başlangıcı $C(i)_{0}=20.0$ olması durumunda elde edilmiştir. $\mathrm{BFO}$ algoritması diğer etkilerin incelenmesinde olduğu gibi sürü etkileşiminin etkisi incelenirken de 30 bağımsız rastgele çalıştırma gerçekleştirilerek uygulanmıştır.

On çubuklu düzlem kafes yapı için sürü etkileşimi ihmal edildiğinde 30 analizden elde edilen ortalama yapı ağırlığ $20855.0 \mathrm{~N}$ olmuştur. Aynı problem için sürü etkileşimi dahil edildiğinde ortalama yapı ağırlığ 20844.4N olarak elde edilmiştir. İki çözüm arasındaki fark \%0.051 olmaktadır. On çubuklu düzlem kafes yapı probleminde sürü etkileşimi ihmal edilmesi durumunda ortalama 79127 yapı analizi gerçekleştirilirken, sürü

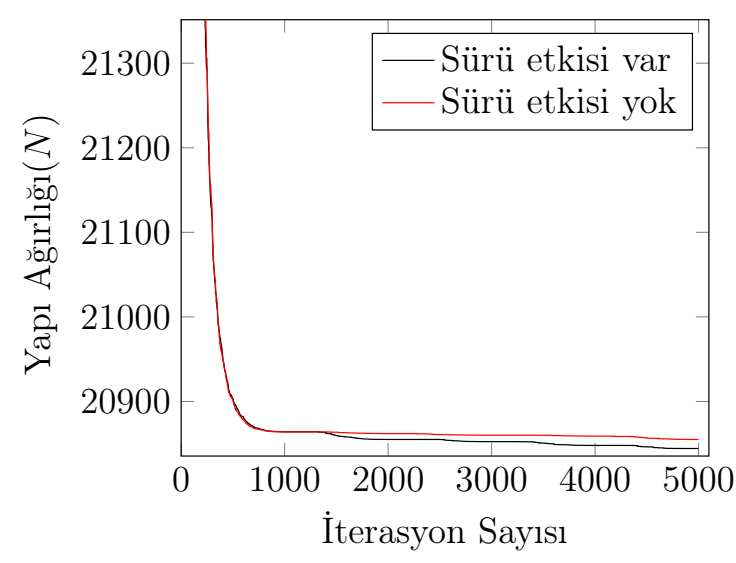

Şekil 12. 10 çubuklu kafes yapı için sürü etkileşimi etkisi

etkileşiminin dahil edilmesi halinde ortalama 80554 yapı analizi gerçekleştirilmiştir. Yapı analizleri arasında fark olmadığı söylenebilir.

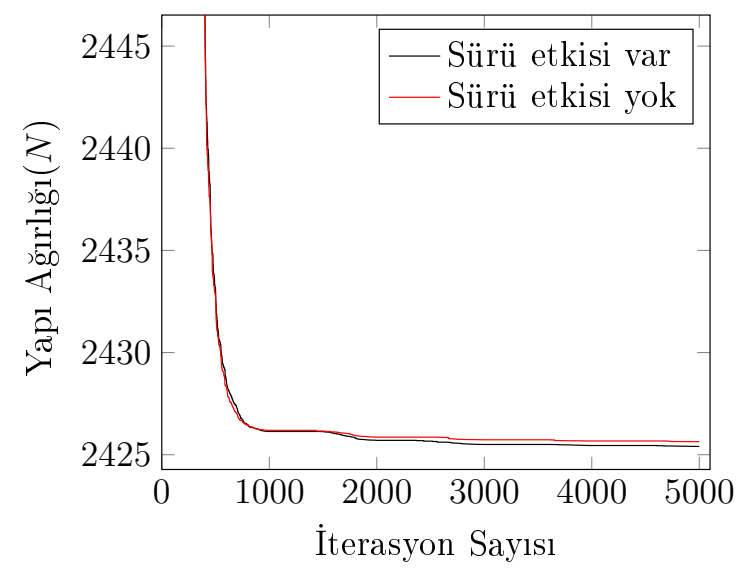

Şekil 13. 25 çubuklu kafes yapı için sürü etkileşimi etkisi

Yirmi beş çubuklu uzay kafes probleminde ortalama yapı ağırlıkları sürü etkileşimi ihmal edilmesi ve dahil edilmesi durumlarında sirasıyla $2425.7 N$ ve $2425.4 N$ olarak elde edilmiştir. İki çözüm arasındaki fark \%0.011 olmaktadır. Bunun yanında sürü etkileşimi ihmal edilmesi durumunda ortalama 100343 yapı analizi gerçekleştirilirken, sürü etkileşiminin dahil edilmesi halinde ortalama 100913 yapı analizi gerçekleştirilmiştir. İki durum arasındaki ortalama yapı analizi farkı yok denilebilecek seviyededir.

\subsection{Kafes yapı örnek sonuçları}

Bakteri sayısı $S_{b}=40$, yüzme sayısı $N_{s}=100$, kemotaksis sayısı $N_{c}=50$, üreme sayısı $N_{r e}=20$, ortadan kaldırmayeniden dağılma sayısı $N_{e d}=5$ ve adım uzunluğu değişken olarak kullanılması durumunda on çubuklu düzlem kafes için BFO algoritmasından elde edilen sonuçlar Tablo 8'de verilmiştir. Aynı tabloda farklı çözüm yöntemleri ile aynı problemi ele alan çeşitli araştırmacıların elde ettikleri sonuçlar da yer almaktadır. Yirmi beş çubuklu düzlem kafes yapı problemi için de aynı parametreler kullanılarak elde edilen sonuçlar Tablo 9'da yer almaktadır. Yetmiş iki çubuklu uzay kafes yapının optimum çözümünden elde edilen değerler Tablo 10'da yer almaktadır. BFO 
Tablo 8. On çubuklu düzlem kafes yapı sonuçları

Kesit Alanları $\left(\mathrm{cm}^{2}\right)$

\begin{tabular}{|c|c|c|c|c|c|c|}
\hline Grup No. & $\begin{array}{c}\text { Lee ve } \\
\text { Geem } \\
{[29]}\end{array}$ & $\begin{array}{l}\text { Li ve di } \breve{g} \text {. } \\
\quad[30]\end{array}$ & $\begin{array}{c}\text { Farshi ve } \\
\text { Alinia-Ziazi } \\
{[31]}\end{array}$ & $\begin{array}{c}\text { Sönmez } \\
\text { [12] }\end{array}$ & $\begin{array}{c}\text { Aslani ve diğ. } \\
\text { [32] }\end{array}$ & Bu çalışma \\
\hline 1 & 150.000 & 150.664 & 151.787 & 151.413 & 150.703 & 151.322 \\
\hline 2 & 0.658 & 0.645 & 0.645 & 0.652 & 0.645 & 0.645 \\
\hline 3 & 166.000 & 164.529 & 163.187 & 162.832 & 162.038 & 159.813 \\
\hline 4 & 93.613 & 91.935 & 92.748 & 92.606 & 92.580 & 92.903 \\
\hline 5 & 0.645 & 0.645 & 0.645 & 0.645 & 0.645 & 0.645 \\
\hline 6 & 12.755 & 12.723 & 12.710 & 12.710 & 12.710 & 12.710 \\
\hline 7 & 78.774 & 79.761 & 80.026 & 80.084 & 80.116 & 80.826 \\
\hline 8 & 81.355 & 83.187 & 82.742 & 83.180 & 82.716 & 84.103 \\
\hline 9 & 131.355 & 131.329 & 131.161 & 131.187 & 131.658 & 131.567 \\
\hline 10 & 0.645 & 0.652 & 0.645 & 0.645 & 0.645 & 0.645 \\
\hline $\mathrm{W}(N)$ & 20767.9 & 20805.6 & 20807.9 & 20804.7 & 20804.3 & 20806.9 \\
\hline Aşılan k1sıt & $3.561 \times 10^{-3}$ & $25.000 \times 10^{-6}$ & - & - & - & 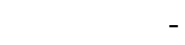 \\
\hline
\end{tabular}

Tablo 9. Yirmi beş çubuklu uzay kafes yapı sonuçları

Kesit Alanları $\left(\mathrm{cm}^{2}\right)$

\begin{tabular}{crrrr} 
Grup No. & $\begin{array}{c}\text { Li ve di } \text { g. } \\
{[30]}\end{array}$ & $\begin{array}{c}\text { Sönmez } \\
{[12]}\end{array}$ & $\begin{array}{c}\text { Farshi ve } \\
\text { Alinia-Ziazi } \\
{[31]}\end{array}$ & Bu çalışma \\
\hline 1 & 0.065 & 0.071 & 0.065 & 0.065 \\
2 & 12.710 & 12.768 & 12.890 & 12.884 \\
3 & 19.458 & 19.374 & 19.245 & 19.213 \\
4 & 0.065 & 0.065 & 0.065 & 0.065 \\
5 & 0.065 & 0.065 & 0.065 & 0.065 \\
6 & 4.477 & 4.452 & 4.413 & 4.413 \\
7 & 10.845 & 10.832 & 10.806 & 10.806 \\
8 & 17.052 & 17.110 & 17.206 & 17.206 \\
$\mathrm{~W}(N)$ & 2425.1 & 2425.1 & 2425.9 & 2425.0 \\
\hline
\end{tabular}

algoritmasında her üç problem için de başlangıç adım uzunluğu $C(i)_{0}=20.0$ olarak alınmıştır. Sürü etkileşimi ihmal edilmiştir.

Tavsiye edilen parametrelerin kullanılması ile üç örnek problem için elde edilen en hafif kafes yapı ağırlıkları Tablo 8, Tablo 9 ve Tablo 10'da verilmektedir. On çubuklu düzlem kafes yapı örneği için elde edilen en hafif yapı ağırlığının referans alınan beş değerden dördünden çok az da olsa daha ağır olduğu görülmektedir. Ancak literatürde verilen sonuçlardan ikisinin optimizasyon probleminin kısıtlarını bir miktar aştığı göz ardı edilmemelidir $\mathrm{Bu}$ çalışmada elde edilen sonuçların tamamında üç örnek problem için de aşılan kısıt bulunmamaktadır. Bu açıdan bakıldığında elde edilen sonucun literatür ile uyumlu olduğu değerlendirilmektedir. Yirmi beş çubuklu uzay kafes probleminde ise bu çalışmada elde edilen en hafif yapı ağırlığı referans alınan çalışmalara göre çok az daha hafif olarak elde edilmiştir. Bu örnek problemin sonuçlarının da literatürdeki sonuçlarla uyumlu olduğu görülmektedir. Benzer şekilde yetmiş iki çubuklu uzay kafes yapı örneğinde de literatür sonuçları ile yakın değerlerin elde edildiği görülmektedir.

On çubuklu düzlem kafes yapı ve yirmi beş çubuklu uzay kafes yapı örneklerinin 30 farklı çözümü sonunda elde edilen varyasyon katsayısı değerleri gerçekleştirilen analizler ile beraber önceki bölümlerde paylaşılmıştı. Yetmiş iki çubuklu uzay kafes yapının 30 bağımsız analizi sonunda ortaya çıkan en hafif yapı ağırlığı $1693.7 \mathrm{~N}$ olmaktadır. Bunun yanında ortalama yapı ağırlıkları $1705.7 N$ ve elde edilen en kötü yapı ağırlığı değeri ise 1738.9N'dur. Bu örnek için standart sapma 2.61 ve varyasyon katsayısıs ise \%0.68 olmaktadır. Analizlerden bağımsız olarak çözülen çubuk sayısı diğer iki örneğe göre nispeten fazla olan bu örnek problemden elde edilen bulguların diğer iki örnek problemden elde edilenlerle uyumlu olduğu görülmektedir.

\section{Tartışma ve Sonuç}

Bakteri yiyecek arama algoritmasının kafes yapıların en hafif tasarımı problemlerinde kullanılması durumunda yüzme sayısının 10 olarak kullanılmasının -bir miktar adım uzunluğu parametresine bağlı olmakla beraberyetersiz kaldığı görülmüştür. Yüzme sayısının 100 veya 1000 olarak seçilmesi durumunda elde edilecek sonuçlar arasındaki farkın önemsiz seviyelerde kaldığı ancak gerekli yapı analizi sayılarının oldukça fazla olduğu görülmektedir. $\mathrm{Bu}$ nedenle yüzme sayısının 100 olarak kullanılması tavsiye edilmektedir. Adım uzunluğu paramatresinin yüzme sayılarının farklı değerlerine etki ettiği çalışmanın bulgularından anlaşılmakla birlikte her farklı problem için 
Tablo 10. 72 çubuklu uzay kafes yapı sonuçları

\begin{tabular}{cccc}
\hline \multicolumn{5}{c}{ Kesit Alanları $\left(\mathrm{cm}^{2}\right)$} \\
Grup No. & $\begin{array}{c}\text { Dede ve } \\
\text { diğ. } \\
{[35]}\end{array}$ & $\begin{array}{c}\text { Camp } \\
{[33]}\end{array}$ & Bu çalışma \\
\hline 1 & 10.98 & 11.99 & 11.70 \\
2 & 3.20 & 3.26 & 3.31 \\
3 & 0.65 & 0.65 & 0.65 \\
4 & 0.65 & 0.65 & 0.65 \\
5 & 8.31 & 8.05 & 8.75 \\
6 & 3.03 & 3.40 & 3.37 \\
7 & 0.65 & 0.65 & 0.65 \\
8 & 0.65 & 0.65 & 0.65 \\
9 & 3.26 & 3.36 & 3.23 \\
10 & 3.55 & 3.34 & 3.61 \\
11 & 0.70 & 0.65 & 0.65 \\
12 & 0.76 & 0.65 & 0.65 \\
13 & 0.99 & 1.01 & 1.03 \\
14 & 3.90 & 3.55 & 3.29 \\
15 & 2.85 & 2.53 & 2.74 \\
16 & 3.90 & 3.82 & 3.46 \\
W(N) & 1700.8 & 1689.7 & 1693.7 \\
\hline
\end{tabular}

adım uzunluğunun hangi değer seçilmesi gerektiği ile ilgili olarak deneme-yanılma süreciyle belirlenmesinin gerektiği anlaşılmaktadır. Bunun yerine bu çalışmada önerilen adım uzunluğu parametresinin üreme iterasyonlarına bağlı olarak değişken olarak kullanılması adım uzunluğunun hangi değer olarak kullanılması problemini ortadan kaldırdığı görülmektedir.

Algoritmada kullanılan bakteri sayısının 40 ve daha fazla olması durumunda kemotaksis sayısinın da 50 ve üzeri seçilmesi halinde elde edilen sonuçların dağılımı ve değerlerinin yaklaşık olarak aynı olduğu söylenebilir. Bakteri sayısının artmasıyla birlikte elde edilen yapı ağırlıkları az miktarda iyileşirken gerçekleştirilmesi gereken yapı analizi sayıları büyük oranda artmaktadır. $\mathrm{Bu}$ durum kemotaksis sayıları için de geçerlidir. Bakteri sayısının 40, kemotaksis sayısının 50 olarak uygulanması makul sürelerde tatmin edici sonuçların alınmasını sağlayacaktır.

Üreme sayısı lokalde arama iterasyon sayısını, ortadan kaldırma-yeniden dağılma sayısı ise aramanın yalnızca lokalde kalmamasını sağlamak amaciyla kullanılan parametrelerdir. $\mathrm{Bu}$ değerlerin mümkün mertebe yüksek seçilmesi daha iyi sonuçların elde edilmesini sağlayabileceği düşünülse de bu parametrelerdeki artışın gerekli kıldığı yapı analizi sayısı oldukça fazla olmaktadır. Buna karşılık yapı ağırlı̆̆ındaki azalma oranı analiz sayısı ile karşılaştırıldığında aradaki ilişkinin doğrusal olmadığı anlaşılmaktadır. Elde edilen bulgular göz önünde tutulduğunda üreme sayısının 20, ortadan kaldırmayeniden dağılma sayısının ise 5 olarak kullanılması durumunda makul sürelerde uygun sonuçların alınabildiğgi, algoritmanın farklı zamanlarda çalıştırıldığında elde edilen sonuçlar arasındaki varyasyon katsayılarının düşük seviyelerde kaldığı görülmektedir.

Sürü etkileşiminin dahil edilmesi ve ihmal edilmesi durumları arasında yapı ağırlığı açısından bakıldı ̆̆ında iki çözüm arasındaki farkın \%0.05 ve altında olduğu

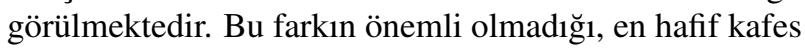
yapı tasarımı problemlerinde sürü etkileşiminin ihmal edilebileceği düşünülmektedir.

Bakteri yiyecek arama optimizasyon algoritmasının topolojisi belirli olan en hafif kafes yapı tasarımı problemlerinde başarılı olarak uygulanabileceği görülmektedir. Bunun yanında en hafif kafes yapı tasarımı problemleri için algoritmada kullanılacak parametre değerlerinin belirlenmesi ile ilgili olarak yapılan çalışmaların uygun değerlerin seçiminde yol gösterici olacağı düşünülmektedir. Ek olarak algoritmanın önemli parametrelerinden olan adım uzunluğunun tespiti ile ilgili önerilen tekniğin de daha az yapı analizi ile daha hafif yapıların elde eldilmesine katkı sağladığı sonucuna varılmaktadır.

\section{Kaynakça}

[1] Dorn, W. S., 1964. Automatic design of optimal structures, Journal de mecanique $325-52$.

[2] Rajeev, S., Krishnamoorthy, C. S, 1997. Genetic Algorithms-Based Methodologies for Design Optimization of Trusses, Journal of Structural Engineering, 123 (3)

[3] Dorigo, M., Di Caro, G., 1999. Ant colony optimization: a new meta-heuristic, Proceedings of the 1999 Congress on Evolutionary Computation-CEC99, 6-9 July, Washington, 1470-1477.

[4] Kaveh, A., Talatahari, S., 2009. A particle swarm ant colony optimization for truss structures with discrete variables, Journal of Constructional Steel Research, 65 (8-9), 1558-1568

[5] Geem, Z. W., Kim, J. H., Loganathan, G., 2001. A New Heuristic Optimization Algorithm: Harmony Search, SIMULATION, 76 (2), 60-68

[6] Glover, F., 1990. Tabu Search - Part I, ORSA journal on Computing, 2 (1)

[7] Glover, F., 1990. Tabu Search-Part II, ORSA Journal on Computing, 2 (1)

[8] Bennage, W. A., Dhingra, A. K., 1995. Optimization of truss topology using tabu search, International Journal for Numerical Methods in Engineering, 38 (23), 4035-4052

[9] Kennedy, J., Eberhart, R., 1995. Particle swarm optimization, International Conference on Neural Networks, 27 Nov.-1 Dec., Perth, 1942-1948

[10] Schutte, J. F., Groenwold, A. A., 2003. Sizing design of truss structures using particle swarms, Structural and Multidisciplinary Optimization, 25 (4), 261-269

[11] Karaboga, D., 2005. An idea based on Honey Bee Swarm for Numerical Optimization, Technical Report TR06, Erciyes University

[12] Sonmez, M., 2011. Artificial Bee Colony algorithm for optimization of truss structures, Applied Soft Computing 11 (2), 2406-2418. 
[13] Sonmez, M., 2011. Discrete optimum design of truss structures using artificial bee colony algorithm, Structural and Multidisciplinary Optimization 43 (1), 85-97.

[14] Passino, K. M., 2002. Biomimicry of bacterial foraging for distributed optimization and control, Control Systems, IEEE, 22 (3), 52-67

[15] Devi, S., Geethanjali, M., 2014. Application of Modified Bacterial Foraging Optimization algorithm for optimal placement and sizing of Distributed Generation, Expert Systems with Applications 41 (6), $2772-2781$

[16] Niu, B., Wang, H., Wang, J., Tan, L., 2013. Multi-objective bacterial foraging optimization, Neurocomputing, 116, 336-345.

[17] Sathya, P. D., Kayalvizhi, R., 2011. Modified bacterial foraging algorithm based multilevel thresholding for image segmentation, Engineering Applications of Artificial Intelligence, 24 (4), 595-615

[18] Majhi. R., Panda, G., Majhi, B., Sahoo, G., 2009. Efficient prediction of stock market indices using adaptive bacterial foraging optimization (ABFO) and $\mathrm{BFO}$ based techniques, Expert Systems with Applications, 36 (6), 10097-10104

[19] S. Hezer, Y. Kara, 2014, Eşzamanlı dağıtımlı ve toplamalı araç rotalama problemlerinin çözümü için bakteriyel besin arama optimizasyonu tabanlı bir algoritma, Gazi Üniversitesi Mühendislik-Mimarlık Fakültesi Dergisi, 28 (2), 373-382

[20] Zhao, W., Wang, L., 2016. An effective bacterial foraging optimizer for global optimization, Information Sciences, 329, 719-735.

[21] Biswas, A., Das, S., Abraham, A., Dasgupta, S., 2010. Stability analysis of the reproduction operator in bacterial foraging optimization, Theoretical Computer Science, 411 (21), 2127-2139

[22] Chen, H., Niu, B., Ma, L., Su, W., Zhu, Y., 2014. Bacterial colony foraging optimization, Neurocomputing, 137, 268-284.

[23] Karaboga, D., Basturk, B., 2007. Artificial Bee Colony (ABC) Optimization Algorithm for Solving Constrained Optimization, 12th International Fuzzy Systems Association World Congress, June 18-21, Mexico, 789-798
[24] Kaveh, A., Bakhshpoori, T., 2013. Optimum Design of Space Trusses Using Cuckoo Search Algorithm With Levy Flights, IJST, Transactions of Civil Engineering, 37 (C1), 1-15.

[25] Cheng, M. Y., Prayogo, D., 2014. Symbiotic Organisms Search: A new metaheuristic optimization algorithm, Computers and Structures, 139, 98-112

[26] Cuevas, E., Cienfuegos, M., 2014. A new algorithm inspired in the behavior of the social-spider for constrained optimization, Expert Systems with Applications, 41 (2), 412-425

[27] Deb, K., 2000. An efficient constraint handling method for genetic algorithms, Computer Methods in Applied Mechanics and Engineering, 186 (2-4), 311-338

[28] Parpinelli, R. S., Teodoro, F. R., Lopes, H. S., 2012. A comparison of swarm intelligence algorithms for structural engineering optimization, International Journal for Numerical Methods in Engineering, 91 (6), 666-684

[29] Lee, K. S., Geem, Z. W., 2004. A new structural optimization method based on the harmony search algorithm, Computers \& Structures, 82 (9-10), 781798

[30] Li, L. J., Huang, Z. B., Liu, F., Wu, Q. H., 2007. A heuristic particle swarm optimizer for optimization of pin connected structures, Computers and Structures, 85 (7-8), 340-349

[31] Farshi, B., Alinia-Ziazi, A., 2010. Sizing optimization of truss structures by method of centers and force formulation, International Journal of Solids and Structures, 47 (18-19), 2508-2524

[32] Aslani, M., Ghasemi, P., Gandomi, A. H., 2018. Constrained mean-variance mapping optimization for truss optimization problems, Structural Design of Tall and Special Buildings, 27 (6), 1-17

[33] Camp, C. V., 2007. Design of Space Trusses Using Big Bang-Big Crunch Optimization, Journal of Structural Engineering, 133 (7), 999-1008

[34] Lamberti, L.. 2008. An efficient simulated annealing algorithm for design optimization of truss structures, Computers \& Structures, 86 (19-20), 1936-1953

[35] Dede, T., Bekirolu, S., Ayvaz, Y., 2011. Weight minimization of trusses with genetic algorithm, in: Applied Soft Computing Journal, 11, 2565-2575 